\title{
Article \\ Germination and the Initial Seedling Growth of Lettuce, Celeriac and Wheat Cultivars after Micronutrient and a Biological Application Pre-Sowing Seed Treatment
}

\author{
Dobrivoj Poštić ${ }^{1}$, Ratibor Štrbanović ${ }^{1}$, Marijenka Tabaković ${ }^{2}{ }^{\circledR}$, Tatjana Popović ${ }^{1}$, Ana Ćirić ${ }^{3}$, \\ Nevena Banjac ${ }^{3}\left(\mathbb{D}\right.$, Nenad Trkulja ${ }^{1}$ and Rade Stanisavljević ${ }^{1, * \text { (D) }}$ \\ 1 Institute for Plant Protection and Environment, 11040 Belgrade, Serbia; pdobrivoj@yahoo.com (D.P.); \\ ratibor.strbanovic@yahoo.com (R.Š.); tanjaizbis@gmail.com (T.P.); trkulja_nenad@yahoo.com (N.T.) \\ 2 Maize Research Institute Zemun Polje, 11185 Belgrade, Serbia; mtabakovic@mrizp.rs \\ 3 Institute for Biological Research Siniša Stanković-National Institute of the Republic of Serbia, University of \\ Belgrade, 11000 Belgrade, Serbia; ancic@ibiss.bg.ac.rs (A.Ć.); mitic.nevena@ibiss.bg.ac.rs (N.B.) \\ * Correspondence: stanisavljevicrade@gmail.com
}

check for updates

Citation: Poštić, D.; Štrbanović, R.; Tabaković, M.; Popović, T.; Ćirić, A.; Banjac, N.; Trkulja, N.; Stanisavljević, R. Germination and the Initial Seedling Growth of Lettuce, Celeriac and Wheat Cultivars after Micronutrient and a Biological Application Pre-Sowing Seed Treatment. Plants 2021, 10, 1913. https://doi.org/10.3390/ plants10091913

Academic Editor: Mariateresa Cardarelli

Received: 3 August 2021

Accepted: 9 September 2021

Published: 14 September 2021

Publisher's Note: MDPI stays neutral with regard to jurisdictional claims in published maps and institutional affiliations.

Copyright: (c) 2021 by the authors. Licensee MDPI, Basel, Switzerland. This article is an open access article distributed under the terms and conditions of the Creative Commons Attribution (CC BY) license (https:// creativecommons.org/licenses/by/ $4.0 /)$.
Abstract: Seed treatments with zinc, boron, biostimulant Coveron and MIX (zinc + boron + Coveron) were applied to three lettuce and three celeriac cultivars. Seeds of three wheat cultivars were treated under laboratory conditions with Trichoderma harzianum and eight Bacillus spp. Seed germination, seedling growth, and the presence of the following pathogens were determined: Fusarium sp., Alternaria sp., Penicillium sp., and Mucor sp. The Coveron treatment was the most effective on lettuce seeds tested in the germination cabinet. Seed germination was higher by $4 \%$ than in the control. Alternatively, germination of seeds treated with boron in the greenhouse was higher by $12 \%$ than in the control. The Coveron treatment had the highest effect on the shoot length, which was greater by 0.7 and $2.1 \mathrm{~cm}$ in the germination cabinet and the greenhouse, respectively. This treatment was also the most effective on the root length. Zn, B, and MIX treatments increased celeriac seed germination by $14 \%$ in the germination cabinet. The $\mathrm{Zn}$ treatment was the most efficient on seeds tested in the greenhouse. The germination was higher by $15 \%$. A significant cultivar $\times$ treatment interaction was determined in both observed species under both conditions. The maximum effect on wheat seed germination ( $8 \%$ ) was achieved with the T. harzianum treatment in the Salazar cultivar. A significant interdependence $(p \leq 0.01$ to $p \leq 0.001$ ) was established between seed germination and the seedling growth. The interrelationship between seed germination and pathogens of all cultivars was negative.

Keywords: Bacillus spp.; boron; Coveron ${ }^{\circledR}$ seed and seedling quality; Trichoderma spp.; zinc

\section{Introduction}

Lettuce (Lactuca sativa L.) is a plant species of the family Asteraceae. World production of lettuce is about 21 million tonnes per year, mainly under temperate climatic conditions [1]. It is traditionally used fresh. Its consumption has a beneficial effect on human health [2]. Celeriac (Apium graveolens L.) is a plant species of the family Apiaceae. In human nutrition, the leaf stalks, leaves, and roots are used as the ingredient in soups, salads, and various other side dishes. It has diuretic, antiseptic, anti-allergy, and anti-inflammatory effects [3]. It also has medicinal properties for the treatment of cardiovascular diseases, high blood pressure, and liver diseases in humans [4].

Both species can be grown in the open field or in any type of a sheltered place (plastichouse, greenhouse) in the organic or the conventional cultivation system. Regardless of the cultivation system, it is necessary that seed germination and the initial seedling growth are high. De-germination can occur due to many reasons: inadequate temperature, light, sowing depth. However, it can be a consequence of the use of poor quality seeds. Growers of both species often complain about low seed germination and a weak initial growth of seedlings. 
Zinc is involved in many biochemical and physiological processes of germination and/or photosynthesis: protein synthesis, membrane building, cell elongation, resistance to abiotic stress, metabolism of carbohydrates, lipids, nucleic acid synthesis, stimulation of auxin synthesis $[5,6]$.

Boron affects the metabolic processes of nucleic acids, carbohydrates, proteins, indol acetic acid. It affects the cell wall synthesis, metabolic activation of phenol, calcium use, cell division $[5,7]$.

Fungal species Trichoderma have a pronounced bio-stimulant effect in germination and other physiological processes, hence in the past decade, it has been widely used in agriculture [8]. Glomus spp. affects the increase of the shoot and root weight [9]. Wheat (Triticum aestivum L.) on a global scale, in addition to rice, is a cereal that is mostly used in human nutrition. Seed-borne fungi can affect seed quality losses such as abortion, rot, necrosis, reduction or elimination of germination capacity, then seedling damage and their nutritive value and also variation in plant morphology [10]. Among the most common plant pathogens in association with wheat seed worldwide are fungi from genera Alternaria sp., Aspergillus sp., Curvularia sp., Drechslera sp., Fusarium sp., Penicillium sp., Mucor sp., Pythium sp., Rhizopus sp. [11]. Yield losses caused by seed-borne pathogens are found to be among 15 to $90 \%$ of untreated wheat seeds grown in fields [12]. Regarding that, numerous research have been conducted for the possibility of biological control of undesirable seed pathogens and increase of germination $[13,14]$. Moreover, there are various investigations in order to increase the areas in organic farming [15]. Variation of the total content of polyphenols and phenolic acids in einkorn, emmer, spelt, and common wheat grain is a function of genotype, wheat species, and crop year [16]. One of the currently used strategies to preserve the health of cultivated plants in organic agriculture is the use of microorganisms that manifest beneficial effects on plant growth and development [17]. Since fungi Trichoderma spp. displayed broad-spectrum of antagonistic activities against various plant pathogens $[18,19]$ it has been considered as the major biocontrol agent in biopesticide industry [20] and used for seed treatment [21]. In recent years, Trichoderma has acquired high importance because of its fungicidal and fertilizing potential [22,23]. Bacillus species also have a positive effect on plant growth and development by regulating the metabolism of plant hormones (auxins, cytokinins, gibberellins), which affects nitrogen fixation and phosphate availability and thus affects seedling growth. In addition, Bacillus spp. produce substances such are antibiotics, enzymes, hydrogen cyanide, which are an important tools in the biological control of plant pathogens [24].

According to Glick, [25] Bacillus spp. belong to plant growth-promoting bacteria (PGPR) and can increase the plant growth through direct or indirect mechanisms. Direct mechanisms involve biological processes such as biological nitrogen-fixation, solubilization of complex organic or inorganic nutrients, sequestering of iron via siderophore production, and modulating phytohormone levels such as gibberellins, cytokinins, indole acetic acid (IAA), and ethylene.

The aim of this study is: (i) to determine germination and the initial growth of seedlings of three lettuce and three celeriac cultivars after pre-sowing seed treatments with zinc, boron, then mixture of zinc, boron, and the biological product-Coveron, and Coveron alone, in the germination cabinet (seeds placed on sand) and the greenhouse conditions (seeds placed on soil-these conditions are close to conventional production conditions); (ii) to examine three cultivars of wheat seed for the effect of treatments with Trichoderma harzianum isolate and eight isolates of Bacillus spp. on the germination and seedling development and influence on the presence of fungal seed plant pathogens under laboratory conditions.

\section{Results and Discussion}

Extremely high temperatures before the seed reaches physiological maturity to reduce the plant ability to form assimilates are necessary for the synthesis of storage compounds required for germination [26]. Moreover, due to high temperatures the seed suffers physio- 
logical damage to the extent that its ability to germinate is reduced [27]. However, when the temperature is similar and the application of cropping practices in production is the same, then the conditions for the growth, development, and maturation are the same, and the quality of seeds is uniform [28]. In our tests, the influence of location was not significant in any of the examined species, probably because the distance of production plots was not more than two kilometers. Seed production was performed in the vicinity of the city of Subotica for lettuce and celeriac, and near the city of Pančevo for wheat. During the filling period and grain maturity, the weather conditions in the two-year testing period were similar on plots for lettuce, celeriac, and wheat production, which probably affected the year without affecting seed germination and seedling quality.

Effects of the cultivar $\times$ location $(A \times C)$, cultivar $\times$ year $(A \times D)$, treatment $\times$ location $(B \times C)$, treatment $\times$ year $(B \times D)$, and location $\times$ year $(C \times D)$ interactions on germination and the seedling growth were not significant in any of the species $(p \geq 0.05)$. On the other hand, effects of factors A and B, as well as their interactions, on the observed traits in the germination cabinet and the greenhouse were significant in both species $(p \leq 0.05$ to $p \leq 0.01)$.

\subsection{Lettuce Seed}

\subsubsection{Germination}

Seed priming is an extensively used practice to increase the rate and uniformity of seed germination that can be a suitable alternative for wheat seedlings to provide the higher yield. The seed treatment using biological agents including a number of Trichoderma species was an eco-friendly method used to improve germination in other important grasses such as rice [29], maize, and oaths [30-33]. Although Trichoderma species showed the wide interaction potential associating with numerous plant species, some specificity in Trichoderma spp. plant species/cultivar relation has been also found [34].

Zinc is involved in the stabilization of cell membranes, detoxification of free radicals, secondary metabolism, and other biochemical and physiological processes during germination and the early growth [35]. Boron affects metabolism of starch, thus significantly affects the rate of both, germination and the initial seedling growth [36]. According to Mondal and Bose [37], micronutrients can be applied to crops through soil, leaves, or seeds. The micronutrient application through the seed treatment has numerous advantages: it is easy to apply; it is cost effective; and it highly affects germination and the initial seedling growth. As stated by Aboutalebian et al. [38], the wheat seed priming with zinc resulted in the significant increase in germination and the initial seedling growth. Furthermore, maize seed priming with zinc led to the increase of germination under conditions of both, laboratory and filed $[39,40]$, which resulted in the yield increase by up to $27 \%$ [41]. According to Rahman et al. [42], rice seeds treated with boron had higher and faster emergence of the initial seedling growth, but it was important that the boron concentration was $0.001 \%$ or $0.1 \%$, while boron concentration of $0.5 \%$ was ineffective. The application of the optimal $\mathrm{Zn}$ concentration to chili seeds affected the increase of germination by $4 \%$, root length by $0.45 \mathrm{~cm}$, and the shoot length by $0.09 \mathrm{~cm}$ [43]. Poštić et al. [44] applied the combination of Trichoderma + Glomus to pepper seeds and determined the increase of seed germination by $4-6 \%$ and $3-4 \%$ during the first and the second year of investigation, respectively.

Similar results were reported by Štrbanović et al. [45]. These authors treated pepper seeds with zinc and boron prior to sowing and found the germination rate to be higher by $5 \%$ and $6 \%$, shoot growth higher by $1.3 \mathrm{~cm}$ and $1.2 \mathrm{~cm}$, and the root growth higher by $0.8 \mathrm{~cm}$. Nevertheless, there are studies in which seeds were treated with zinc or boron and no significant increases in germination and/or the seedling growth were achieved: for instance, rice [46] and wheat [47]. Therefore, based on literature data, the effect of the boron and zinc application on germination and initial seedling growth significantly differs based on plant species, genetics, i.e., a cultivar or a hybrid of the same species, the application method, or the concentration of microelements. 
Lettuce seeds were stored in the germination cabinet, and after seven days, germination was higher in treatments than in the control: by $4 \%$ (Coveron), 3\% (Zn and MIX), and by $2 \%$ (B) (the average of all cultivars). However, each cultivar differently responded to treatments: Coveron was the optimal treatment for cultivars Genius and Majska kraljica, with germination higher by $4 \%$ and $5 \%$, respectively; $\mathrm{Zn}$ and B were the optimal treatments for cultivar Endivia and they increased germination by $5 \%$ (Table $1 \mathrm{~b}$ ).

Table 1. Germination after treatments applied to lettuce cultivars.

\begin{tabular}{|c|c|c|c|c|c|c|}
\hline \multicolumn{7}{|c|}{ Results Obtained in Germination Cabinets (a) } \\
\hline \multirow[t]{2}{*}{ Traits } & \multirow[t]{2}{*}{ Treatment } & \multicolumn{3}{|c|}{ Cultivar } & \multirow[t]{2}{*}{ Average } & \multirow[t]{2}{*}{ CV $(\%)$} \\
\hline & & Genius & Majska Kraljica & Endivia & & \\
\hline \multirow{8}{*}{$\begin{array}{l}\text { Germination } \\
(\%)\end{array}$} & & & & & & \\
\hline & Control & $88 \pm 0.58 b$ & $86 \pm 0.19 b$ & $86 \pm 0.12 b$ & 87 & 1.33 \\
\hline & Zinc & $89 \pm 0.33 \mathrm{ab}$ & $89 \pm 0.33 a b$ & $91 \pm 0.18 \mathrm{a}$ & 90 & 1.29 \\
\hline & Boron & $89 \pm 0.28 \mathrm{ab}$ & $88 \pm 0.48 \mathrm{ab}$ & $91 \pm 0.42 \mathrm{a}$ & 89 & 1.71 \\
\hline & MIX & $91 \pm 0.72 \mathrm{a}$ & $90 \pm 0.63 a$ & $90 \pm 0.60 \mathrm{a}$ & 90 & 0.64 \\
\hline & Coveron & $92 \pm 0.52 \mathrm{a}$ & $91 \pm 0.51 \mathrm{a}$ & $89 \pm 0.50 \mathrm{ab}$ & 91 & 1.68 \\
\hline & Average & 89 & 88 & 90 & - & - \\
\hline & $\mathrm{CV} \%$ & 1.41 & 1.94 & 2.66 & - & - \\
\hline \multicolumn{7}{|c|}{ Results Obtained in Greenhouses (b) } \\
\hline & Control & $74 \pm 0.54 \mathrm{~b}$ & $79 \pm 0.12 c$ & $83 \pm 0.58 b$ & 79 & 5.73 \\
\hline & Zinc & $87 \pm 0.63 \mathrm{a}$ & $95 \pm 0.33 \mathrm{a}$ & $89 \pm 0.58 \mathrm{a}$ & 90 & 4.61 \\
\hline & Boron & $88 \pm 0.81 \mathrm{a}$ & $94 \pm 0.58 \mathrm{a}$ & $90 \pm 0.58 \mathrm{a}$ & 91 & 3.37 \\
\hline & MIX & $90 \pm 0.45 \mathrm{a}$ & $93 \pm 0.50 \mathrm{ab}$ & $88 \pm 0.58 \mathrm{a}$ & 90 & 2.79 \\
\hline & Coveron & $88 \pm 0.16 \mathrm{a}$ & $91 \pm 0.76 b$ & $89 \pm 0.58 \mathrm{a}$ & 89 & 1.71 \\
\hline & Average & 85 & 90 & 85 & - & - \\
\hline & $\mathrm{CV} \%$ & 7.57 & 7.24 & 4.53 & - & - \\
\hline
\end{tabular}

Tukey's multiple range test, significant effect $p \leq 0.05$, different small letters, $a, b \ldots x$, values are mean \pm standard error of the mean, Coveron - (commercial product consisting of Trichoderma atroviride, Glomus mosseae, Glomus intraradices), MIX - (zinc $\mathrm{ZnSO}_{4}+$ boron $0.025 \%$ + biological product - Coveron).

After 10 days of storage of treated seeds in the greenhouse, germination compared to the control, was higher by $12 \%$ (B), $11 \%$ (Zn and MIX), and 10\% (Coveron) (Table $1 \mathrm{~b}$ ). MIX was the optimal treatment for cultivar Genius and it increased germination by $16 \%$; Zn was the optimal treatment for cultivar Majska kraljica and it also increased germination by $16 \%$, while B was the optimal treatment for cultivar Endivia and it increased germination by $7 \%$. The resulting differences in seed germination were statistically significant $(p \leq 0.05)$ in all observed lettuce cultivars in both, the germination cabinet and the greenhouse (Table 1b).

\subsubsection{Shoot Length}

Generally, in comparison to the control, the highest effect, on average, in the germination cabinet, on the shoot length was expressed by the Coveron treatment and the length was greater by $0.5 \mathrm{~cm}$ and $1.2 \mathrm{~cm}$ in cultivars Genius and Endivia, respectively. Cultivar Majska kraljica was mostly affected by B and the shoot was longer by $0.6 \mathrm{~cm}$ (Table 2a). The highest effect, on average, on all cultivars in the greenhouse, was recorded with Coveron, and in comparison to the control, the shoot length was longer by $2.1 \mathrm{~cm}$. The effect of all treatments on shoot length was the same, with a coefficient of variation $(\mathrm{CV})$ of no more than $4.5 \%$. The effect of the cultivar $\times$ Coveron treatment interaction in the greenhouse was the highest on the Endevia seeds $(8.1 \mathrm{~cm})$. The seed treatment with Coveron was optimal for all observed cultivars, while the optimal Zn or B treatment differed over cultivars (Table 2b). 
Table 2. Growth of shoot length after treatments applied to lettuce cultivars.

\begin{tabular}{|c|c|c|c|c|c|c|}
\hline \multicolumn{7}{|c|}{ Results Obtained in Germination Cabinets (a) } \\
\hline \multirow[t]{2}{*}{ Traits } & \multirow[t]{2}{*}{ Treatment } & \multicolumn{3}{|c|}{ Cultivar } & \multirow[t]{2}{*}{ Average } & \multirow[t]{2}{*}{$\mathrm{CV}(\%)$} \\
\hline & & Genius & Majska Kraljica & Endivia & & \\
\hline \multirow{2}{*}{\multicolumn{7}{|c|}{$\begin{array}{l}\text { Shoot length } \\
(\mathrm{cm})\end{array}$}} \\
\hline & Control & $4.5 \pm 0.16 \mathrm{~b}$ & $3.7 \pm 0.11 b$ & $3.1 \pm 0.13 b$ & 3.8 & 18.6 \\
\hline & Zinc & $4.6 \pm 0.28 \mathrm{ab}$ & $4.2 \pm 0.55 \mathrm{a}$ & $3.7 \pm 0.16 \mathrm{a}$ & 4.2 & 10.8 \\
\hline & Boron & $4.7 \pm 0.58 \mathrm{ab}$ & $4.3 \pm 0.68 \mathrm{a}$ & $3.8 \pm 0.72 \mathrm{a}$ & 4.3 & 10.6 \\
\hline & MIX & $4.8 \pm 0.62 \mathrm{a}$ & $4.1 \pm 0.19 \mathrm{a}$ & $3.6 \pm 0.55 \mathrm{ab}$ & 4.2 & 14.5 \\
\hline & Coveron & $5.0 \pm 0.50 \mathrm{a}$ & $4.2 \pm 0.38 \mathrm{a}$ & $4.3 \pm 0.14 \mathrm{a}$ & 4.5 & 9.68 \\
\hline & Average & 4.7 & 4.1 & 3.7 & - & - \\
\hline & CV \% & 4.08 & 5.72 & 11.6 & - & - \\
\hline \multicolumn{7}{|c|}{ Results Obtained in Greenhouses (b) } \\
\hline & Control & $5.9 \pm 0.76 b$ & $5.5 \pm 0.14 b$ & $5.6 \pm 0.50 \mathrm{c}$ & 5.7 & 3.67 \\
\hline & Zinc & $7.2 \pm 0.32 \mathrm{a}$ & $6.9 \pm 0.59 \mathrm{a}$ & $6.6 \pm 0.14 b$ & 6.9 & 4.35 \\
\hline & Boron & $6.9 \pm 0.12 a$ & $7.0 \pm 0.12 \mathrm{a}$ & $6.5 \pm 0.16 b$ & 6.8 & 3.89 \\
\hline & MIX & $7.3 \pm 0.45 \mathrm{a}$ & $7.3 \pm 0.14 \mathrm{a}$ & $7.8 \pm 0.25 \mathrm{a}$ & 7.5 & 3.87 \\
\hline & Coveron & $7.6 \pm 0.65 \mathrm{a}$ & $7.7 \pm 0.62 \mathrm{a}$ & $8.1 \pm 0.36 \mathrm{a}$ & 7.8 & 3.39 \\
\hline & Average & 7.0 & 6.9 & 6.9 & - & - \\
\hline & $\mathrm{CV} \%$ & 9.36 & 12.1 & 14.8 & - & - \\
\hline
\end{tabular}

Tukey's multiple range test, significant effect $p \leq 0.05$, different small letters, $\mathrm{a}, \mathrm{b} \ldots \mathrm{x}$, values are mean \pm standard error of the mean Coveron - (commercial product consisting of Trichoderma atroviride, Glomus mosseae, Glomus intraradices), MIX - (zinc $\mathrm{ZnSO}_{4}+$ boron $0.025 \%+$ biological product - Coveron).

\subsubsection{Root Length}

The average root length of seeds tested in the germination cabinet, in comparison to the control, was longer by $0.5 \mathrm{~cm}, 0.4 \mathrm{~cm}, 0.3 \mathrm{~cm}$, and $0.3 \mathrm{~cm}$ when seeds were treated with Coveron, MIX, Zn, and B, respectively (Table 3a). MIX was the optimal treatment for cultivar Genius with the root length increased by $0.4 \mathrm{~cm}$. Coveron was the optimal treatment for cultivar Majska kraljica, and the root length increased by $0.6 \mathrm{~cm}$, while Coveron and $\mathrm{Zn}$ were the most efficient treatments for cultivar Endivia with the root length longer by $0.8 \mathrm{~cm}$ and $0.7 \mathrm{~cm}$, respectively.

Table 3. Growth of root length after treatments applied to lettuce cultivars.

\begin{tabular}{|c|c|c|c|c|c|c|}
\hline \multicolumn{7}{|c|}{ Results Obtained in Germination Cabinets (a) } \\
\hline \multirow[t]{2}{*}{ Traits } & \multirow[t]{2}{*}{ Treatment } & \multicolumn{3}{|c|}{ Cultivar } & \multirow[t]{2}{*}{ Average } & \multirow[t]{2}{*}{ CV $(\%)$} \\
\hline & & Genius & Majska Kraljica & Endivia & & \\
\hline $\begin{array}{l}\text { Root length } \\
\quad(\mathrm{cm})\end{array}$ & $\begin{array}{l}\text { Control } \\
\text { Zinc } \\
\text { Boron } \\
\text { MIX } \\
\text { Coveron } \\
\text { Average } \\
\text { CV \% }\end{array}$ & $\begin{array}{c}1.1 \pm 0.11 \mathrm{~b} \\
1.2 \pm 0.56 \mathrm{ab} \\
1.3 \pm 0.12 \mathrm{ab} \\
1.5 \pm 0.62 \mathrm{a} \\
1.4 \pm 0.50 \mathrm{a} \\
1.3 \\
12.2\end{array}$ & $\begin{array}{c}1.8 \pm 0.72 \mathrm{~b} \\
2.1 \pm 0.58 \mathrm{ab} \\
2.1 \pm 0.14 \mathrm{ab} \\
2.2 \pm 0.33 \mathrm{a} \\
2.4 \pm 0.51 \mathrm{a} \\
2.1 \\
10.2\end{array}$ & $\begin{array}{c}0.6 \pm 0.42 \mathrm{~b} \\
1.3 \pm 0.55 \mathrm{a} \\
1.0 \pm 0.18 \mathrm{ab} \\
1.1 \pm 0.14 \mathrm{ab} \\
1.4 \pm 0.56 \mathrm{a} \\
1.1 \\
28.8\end{array}$ & $\begin{array}{l}1.2 \\
1.5 \\
1.5 \\
1.6 \\
1.7 \\
- \\
-\end{array}$ & $\begin{array}{c}51.7 \\
32.2 \\
38.8 \\
34.8 \\
33.3 \\
- \\
-\end{array}$ \\
\hline \multicolumn{7}{|c|}{ Results Obtained in Greenhouses (b) } \\
\hline & $\begin{array}{l}\text { Control } \\
\text { Zinc } \\
\text { Boron } \\
\text { MIX } \\
\text { Coveron } \\
\text { Average } \\
\text { CV \% }\end{array}$ & $\begin{array}{c}0.4 \pm 0.48 \mathrm{~b} \\
0.7 \pm 0.58 \mathrm{a} \\
0.6 \pm 0.52 \mathrm{a} \\
0.6 \pm 0.13 \mathrm{a} \\
0.7 \pm 0.55 \mathrm{a} \\
0.6 \\
20.4\end{array}$ & $\begin{array}{c}0.6 \pm 0.50 \mathrm{~b} \\
0.7 \pm 0.66 \mathrm{ab} \\
0.7 \pm 0.17 \mathrm{ab} \\
0.8 \pm 0.53 \mathrm{a} \\
0.9 \pm 0.88 \mathrm{a} \\
0.7 \\
15.4\end{array}$ & $\begin{array}{c}0.5 \pm 0.77 \mathrm{~b} \\
0.8 \pm 0.65 \mathrm{a} \\
0.8 \pm 0.14 \mathrm{a} \\
0.7 \pm 0.18 \mathrm{a} \\
0.7 \pm 0.22 \mathrm{a} \\
0.7 \\
17.7\end{array}$ & $\begin{array}{l}0.5 \\
0.7 \\
0.7 \\
0.7 \\
0.8 \\
- \\
-\end{array}$ & $\begin{array}{c}20.0 \\
7.87 \\
14.3 \\
14.3 \\
15.1 \\
- \\
-\end{array}$ \\
\hline
\end{tabular}

Tukey's multiple range test, significant effect $p \leq 0.05$, different small letters, $\mathrm{a}, \mathrm{b} \ldots \mathrm{x}$, values are mean \pm standard error of the mean, Coveron - (commercial product consisting of Trichoderma atroviride, Glomus mosseae, Glomus intraradices), MIX - (zinc $\mathrm{ZnSO}_{4}+\mathrm{boron}^{\circ}$ $0.025 \%$ + biological product - Coveron). 
In the greenhouse, the increase in the root length was $0.3 \mathrm{~cm}$ and $0.2 \mathrm{~cm}$ when Coveron and remaining treatments, respectively, were applied. The response of cultivar Genius to $\mathrm{Zn}$ and Coveron was the best and the increase in the root length was $0.3 \mathrm{~cm}$. Coveron was the most efficient for cultivar Majska kraljica (root longer by $0.3 \mathrm{~cm}$ ), while $\mathrm{Zn}$ and $\mathrm{B}$ treatments were the most efficient for cultivar Endivia (root was also longer by $0.3 \mathrm{~cm}$ ) (Table 3b).

According to the F test, the effect of factors, location (C), and year (D) was not significant (further on in the text the average is presented). The trend of improved germination and the initial growth of seedlings was observed in lettuce seeds of all cultivars in all treatments in both investigation variants (the germination cabinet and the greenhouse), but the difference was not significant $(p \geq 0.05)$ between the control and the $\mathrm{Zn}$ and $\mathrm{B}$ treatments in cultivar Genius and cultivar Majska kraljica, respectively, as well as between the control and the Coveron treatment in cultivar Endivia. The difference in the root growth between the control and Zn and B treatments in cultivar Genius was not significant. Moreover, the difference in the root growth between the control and the MIX treatment was not significant in the cultivar Endivia (Table 4).

Table 4. Factors on germination and the seedling growth after treatments applied to lettuce cultivars.

\begin{tabular}{|c|c|c|c|}
\hline \multicolumn{4}{|c|}{ Results Obtained in Germination Cabinets (F-Test) } \\
\hline Source & Genius & Majska Kraljica & Endivia \\
\hline Cultivar (A) & ** & * & * \\
\hline Treatment (B) & $* *$ & * & * \\
\hline Location (C) & ns & ns & ns \\
\hline Year (D) & ns & ns & ns \\
\hline $\mathrm{A} \times \mathrm{B}$ & * & $*$ & * \\
\hline $\mathrm{A} \times \mathrm{C}$ & ns & ns & ns \\
\hline$A \times D$ & ns & ns & ns \\
\hline$B \times C$ & ns & ns & ns \\
\hline $\mathrm{B} \times \mathrm{D}$ & ns & ns & ns \\
\hline $\mathrm{C} \times \mathrm{D}$ & ns & ns & ns \\
\hline
\end{tabular}

\begin{tabular}{cccc}
\hline & Results Obtained in Greenhouses (F-Test) & \\
\hline Cultivar (A) & $*$ & $*$ & $*$ \\
Treatment (B) & $* *$ & ns & ns \\
Location (C) & ns & ns & ns \\
Year (D) & ns & $*$ & ns \\
A $\times$ B & $*$ & ns & ns \\
A $\times$ C & ns & ns & ns \\
A $\times$ D & ns & ns & ns \\
B $\times$ C & ns & ns & ns \\
B $\times$ D & ns & ns & \\
C $\times$ D & ns &
\end{tabular}

Significancy of the F tests at the: ${ }^{*} p \leq 0.05,{ }^{* *} p \leq 0.01$; ns-not significant $(p \geq 0.05)$; interaction of factors: cultivar $\times$ treatment $(A \times B)$, cultivar $\times$ location $(A \times C)$, cultivar $\times$ year $(A \times D)$, treatment $\times$ location $(B \times C)$, teratment $\times$ year $(B \times D)$, location $\times$ year $(C \times D)$.

The PCA was applied to the lettuce seeds in order to evaluate the relation between cultivars and applied methods. The first and the second principal components (PC-1 and PC-2) accounted for $56.04 \%$ and $19.14 \%$, respectively, of the total data variance, i.e., their mutual projections (Figure 1). This analysis also confirmed that the treatments and cultivars were correlated and classified into the same group, A1 and A2, except for B-Genus (GE), while on the other hand, control treatments were in the second group (B1 and B2) (Figure 1). 


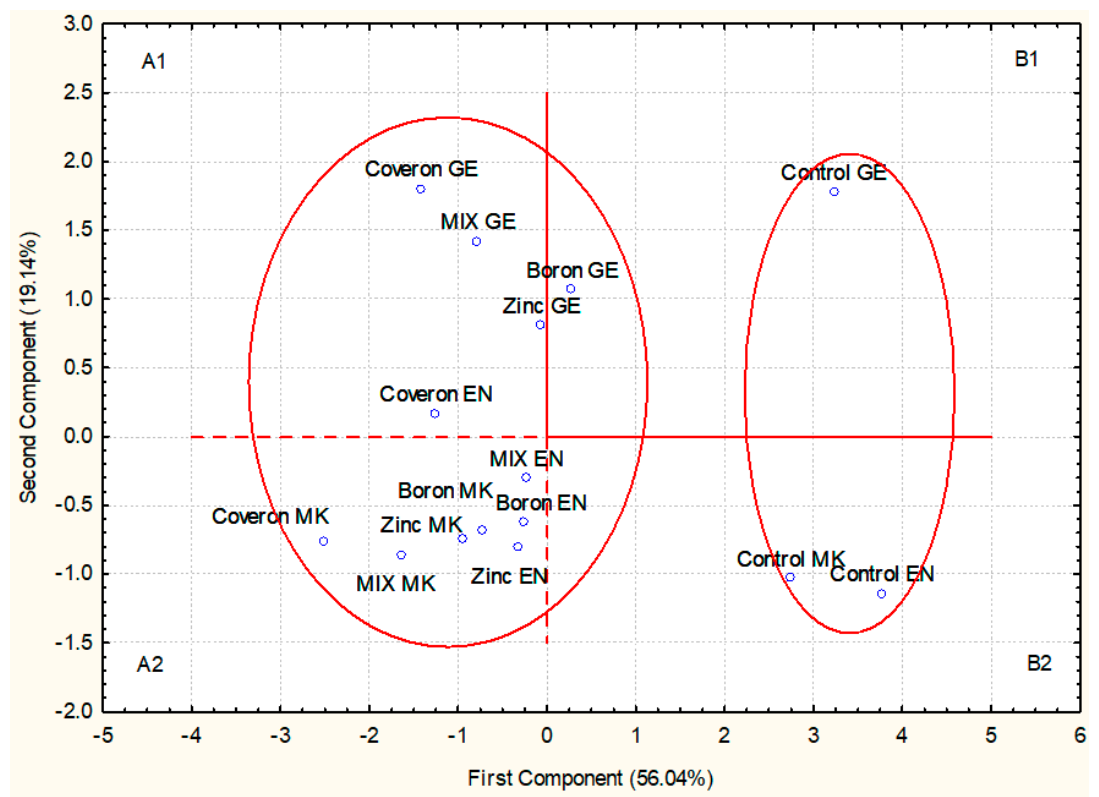

Figure 1. Principal component analysis (PCA) for the treatment effect on seed germination and shoot and root length of lettuce (Lactuca sativa, GE-Genius, MK-Majska kraljica, EN-Endivia).

\subsection{Celeriac Seed}

\subsubsection{Germination}

Germination of three celeriac cultivars was uneven in seeds tested in the germination cabinet. The greatest variation in germination (CV 12.1\%) was recorded in the untreated seeds (control), while the $\mathrm{Zn}$ treatment equally affected all cultivars with the average germination of $88 \%$ and CV $3.64 \%$. The most variable germination within the treatment + control was determined in the celeriac cultivar Cazar (CV 11.0\%). The highest increase in germination in comparison to the control was recorded in cultivar Cezar when $\mathrm{Zn}$ was applied (23\%). The B treatment resulted in germination higher by $10 \%$ in cultivar Omega, while effects of B, MIX, and Coveron treatments were equally good for cultivar Praški krupni (germination was higher by 15\%) (Table 5a).

Table 5. Germination after treatments applied to celeriac cultivars.

\begin{tabular}{|c|c|c|c|c|c|c|}
\hline \multicolumn{7}{|c|}{ Results Obtained in Germination Cabinets (a) } \\
\hline \multirow[t]{2}{*}{ Traits } & \multirow[t]{2}{*}{ Treatment } & \multicolumn{3}{|c|}{ Cultivar } & \multirow[t]{2}{*}{ Average } & \multirow[t]{2}{*}{ CV (\%) } \\
\hline & & Cezar & Omega & Praški Krupni & & \\
\hline $\begin{array}{c}\text { Germination } \\
(\%)\end{array}$ & $\begin{array}{l}\text { Control } \\
\text { Zinc } \\
\text { Boron } \\
\text { MIX } \\
\text { Coveron } \\
\text { Average } \\
\text { CV\% }\end{array}$ & $\begin{array}{c}64 \pm 0.13 \mathrm{c} \\
87 \pm 0.28 \mathrm{a} \\
79 \pm 0.58 \mathrm{ab} \\
82 \pm 0.92 \mathrm{a} \\
78 \pm 0.19 \mathrm{~b} \\
78 \\
11.0\end{array}$ & $\begin{array}{c}79 \pm 0.54 \mathrm{~b} \\
86 \pm 0.28 \mathrm{a} \\
89 \pm 0.34 \mathrm{a} \\
86 \pm 0.22 \mathrm{a} \\
87 \pm 0.77 \mathrm{a} \\
85 \\
4.43\end{array}$ & $\begin{array}{c}80 \pm 0.50 \mathrm{~b} \\
92 \pm 0.45 \mathrm{a} \\
95 \pm 0.84 \mathrm{a} \\
95 \pm 0.67 \mathrm{a} \\
95 \pm 0.55 \mathrm{a} \\
91 \mathrm{a} \\
7.12\end{array}$ & $\begin{array}{c}74 \\
88 \\
88 \\
88 \\
87 \\
- \\
-\end{array}$ & $\begin{array}{l}12.1 \\
3.64 \\
9.22 \\
7.60 \\
9.81 \\
- \\
-\end{array}$ \\
\hline \multicolumn{7}{|c|}{ Results Obtained in Greenhouses (b) } \\
\hline & $\begin{array}{l}\text { Control } \\
\text { Zinc } \\
\text { Boron } \\
\text { MIX } \\
\text { Coveron } \\
\text { Average } \\
\text { CV \% }\end{array}$ & $\begin{array}{c}57 \pm 0.19 \mathrm{c} \\
82 \pm 0.11 \mathrm{a} \\
72 \pm 0.71 \mathrm{~b} \\
72 \pm 0.63 \mathrm{~b} \\
69 \pm 0.54 \mathrm{~b} \\
70 \\
12.7\end{array}$ & $\begin{array}{c}69 \pm 0.10 \mathrm{~b} \\
81 \pm 0.18 \mathrm{a} \\
84 \pm 0.84 \mathrm{a} \\
79 \pm 0.52 \mathrm{ab} \\
82 \pm 0.32 \mathrm{a} \\
79 \\
7.44\end{array}$ & $\begin{array}{c}79 \pm 0.41 \mathrm{c} \\
87 \pm 0.63 \mathrm{~b} \\
91 \pm 0.17 \mathrm{a} \\
86 \pm 0.63 \mathrm{~b} \\
90 \pm 0.48 \mathrm{a} \\
87 \\
5.45\end{array}$ & $\begin{array}{c}68 \\
83 \\
82 \\
79 \\
80 \\
- \\
-\end{array}$ & $\begin{array}{c}16.1 \\
3.86 \\
11.7 \\
8.86 \\
13.2 \\
- \\
-\end{array}$ \\
\hline
\end{tabular}

Tukey's multiple range test, significant effect $p \leq 0.05$, different small letters, $\mathrm{a}, \mathrm{b} \ldots \mathrm{x}$, values are mean \pm standard error of the mean, Coveron - (commercial product consisting of Trichoderma atroviride, Glomus mosseae, Glomus intraradices), MIX - (zinc $\mathrm{ZnSO}_{4}+\mathrm{boron}^{-}$ $0.025 \%$ + biological product - Coveron). 
The $\mathrm{Zn}$ treatment showed the highest efficiency on germination of seeds tested in the greenhouse; the germination was higher by $15 \%$ than the control. The significance of the cultivar $\times$ treatment interaction was the highest in cultivar Cezar with the variation between the applied treatments and the control of $12.7 \%$. Zn was the optimal treatment for cultivar Cezar, while the B treatment was the optimal treatment for cultivars Omega and Praški krupni (Table 5b).

\subsubsection{Shoot Length}

After measuring shoots in seedlings obtained in the germination cabinet, the highest $(0.7 \mathrm{~cm})$, i.e., the lowest $(0.5 \mathrm{~cm})$ increase in the shoot length in relation to the control was recorded in seeds treated with Coveron, i.e., with Zn and B, respectively (average of all observed cultivars).

The treatment effects differed over cultivars. The optimal treatments for cultivar Cezar were B and MIX (shoot growth higher by $0.3 \mathrm{~cm}$ in relation to the control), while Coveron was the optimal treatment for cultivars Omega and Praški krupni (growth higher by $0.8 \mathrm{~cm}$ and $1.0 \mathrm{~cm}$, respectively in relation to the control) (Table 6a).

Table 6. Growth of shoot length after treatments applied to celeriac cultivars.

\begin{tabular}{|c|c|c|c|c|c|c|}
\hline \multicolumn{7}{|c|}{ Results Obtained in Germination Cabinets (a) } \\
\hline \multirow[t]{2}{*}{ Traits } & \multirow[t]{2}{*}{ Treatment } & \multicolumn{3}{|c|}{ Cultivar } & \multirow[t]{2}{*}{ Average } & \multirow[t]{2}{*}{ CV (\%) } \\
\hline & & Cezar & Omega & Praški krupni & & \\
\hline \multirow{8}{*}{$\begin{array}{l}\text { Shoot length } \\
(\mathrm{cm})\end{array}$} & & & & & & \\
\hline & Control & $1.0 \pm 0.63 \mathrm{~b}$ & $1.8 \pm 0.55 \mathrm{~b}$ & $1.8 \pm 0.44 \mathrm{c}$ & 1.5 & 30.1 \\
\hline & Zinc & $1.2 \pm 0.18 \mathrm{a}$ & $2.5 \pm 0.63 \mathrm{a}$ & $2.3 \pm 0.56 b$ & 2.0 & 35.0 \\
\hline & Boron & $1.3 \pm 0.77 \mathrm{a}$ & $2.4 \pm 0.98 \mathrm{a}$ & $2.2 \pm 0.25 b$ & 2.0 & 29.8 \\
\hline & MIX & $1.3 \pm 0.28 \mathrm{a}$ & $2.3 \pm 0.13 \mathrm{a}$ & $2.7 \pm 0.15 \mathrm{a}$ & 2.1 & 34.3 \\
\hline & Coveron & $1.2 \pm 0.14 \mathrm{a}$ & $2.6 \pm 0.42 \mathrm{a}$ & $2.8 \pm 0.76 \mathrm{a}$ & 2.2 & 39.6 \\
\hline & Average & 1.2 & 2.3 & 2.4 & - & - \\
\hline & $\mathrm{CV} \%$ & 10.2 & 13.4 & 17.1 & - & - \\
\hline \multicolumn{7}{|c|}{ Results Obtained in Greenhouses (b) } \\
\hline & Control & $1.7 \pm 0.67 c$ & $1.3 \pm 0.09 c$ & $1.2 \pm 0.72 b$ & 1.4 & 18.9 \\
\hline & Zinc & $2.4 \pm 0.53 b$ & $1.8 \pm 0.17 b$ & $2.0 \pm 0.67 \mathrm{a}$ & 2.1 & 14.8 \\
\hline & Boron & $2.3 \pm 0.45 b$ & $1.8 \pm 0.54 b$ & $1.8 \pm 0.14 \mathrm{a}$ & 2.0 & 14.7 \\
\hline & MIX & $3.0 \pm 0.62 \mathrm{a}$ & $2.1 \pm 0.82 \mathrm{ab}$ & $1.9 \pm 0.17 \mathrm{a}$ & 2.3 & 25.1 \\
\hline & Coveron & $3.1 \pm 0.13 \mathrm{a}$ & $2.4 \pm 0.43 \mathrm{a}$ & $2.0 \pm 0.43 \mathrm{a}$ & 2.5 & 22.3 \\
\hline & Average & 2.5 & 1.9 & 1.8 & - & - \\
\hline & $\mathrm{CV} \%$ & 22.8 & 21.7 & 18.8 & - & - \\
\hline
\end{tabular}

Tukey's multiple range test, significant effect $p \leq 0.05$, different small letters, $\mathrm{a}, \mathrm{b} \ldots \mathrm{x}$, values are mean \pm standard error of the mean, Coveron - (commercial product consisting of Trichoderma atroviride, Glomus mosseae, Glomus intraradices), MIX $-\left(\mathrm{zinc} \mathrm{ZnSO}_{4}+\right.$ boron $0.025 \%$ + biological product - Coveron).

The treatment MIX showed the highest effect on the shoot growth under the greenhouse conditions (CV 25.1\%). The significance of cultivar $\times$ treatment interaction for the shoot growth was the most pronounced in the cultivar Cezar (CV 22.8\%) (Table 6b).

\subsubsection{Root Length}

The root length of seedlings in the germination cabinet varied from $\mathrm{CV} 4.22 \%$ ( $\mathrm{Zn}$ treatment) to CV 9.17\% (MIX treatment). The differences in the root length over cultivars and treatments varied from CV $10.5 \%$ to $23.0 \%$. The longest root of $1.8 \mathrm{~cm}$ was obtained by the application of the Coveron, i.e., MIX treatment on seeds of cultivars Omega, i.e., Praški krupni, respectively (Table 7a). 
Table 7. Growth of root length after treatments applied to celeriac cultivars.

\begin{tabular}{|c|c|c|c|c|c|c|}
\hline \multicolumn{7}{|c|}{ Results Obtained in Germination Cabinets (a) } \\
\hline \multirow[t]{2}{*}{ Traits } & \multirow[t]{2}{*}{ Treatment } & \multicolumn{3}{|c|}{ Cultivar } & \multirow[t]{2}{*}{ Average } & \multirow[t]{2}{*}{ CV $(\%)$} \\
\hline & & Cezar & Omega & Praški krupni & & \\
\hline \multirow{2}{*}{\multicolumn{7}{|c|}{ Root length }} \\
\hline & Control & $1.2 \pm 0.43 b$ & $1.1 \pm 0.63 \mathrm{~b}$ & $1.0 \pm 0.64 \mathrm{c}$ & 1.1 & 9.09 \\
\hline & Zinc & $1.4 \pm 0.16 \mathrm{ab}$ & $1.4 \pm 0.78 \mathrm{ab}$ & $1.3 \pm 0.53 b$ & 1.4 & 4.22 \\
\hline & Boron & $1.5 \pm 0.75 \mathrm{a}$ & $1.6 \pm 0.25 \mathrm{a}$ & $1.3 \pm 0.17 b$ & 1.5 & 10.4 \\
\hline & MIX & $1.5 \pm 0.19 \mathrm{a}$ & $1.7 \pm 0.65 \mathrm{a}$ & $1.8 \pm 0.13 \mathrm{a}$ & 1.7 & 9.17 \\
\hline & Coveron & $1.6 \pm 0.55 \mathrm{a}$ & $1.8 \pm 0.13 \mathrm{a}$ & $1.7 \pm 0.26 \mathrm{a}$ & 1.7 & 5.88 \\
\hline & Average & 1.4 & 1.5 & 1.4 & - & - \\
\hline & $\mathrm{CV} \%$ & 10.5 & 18.3 & 23.0 & - & - \\
\hline \multicolumn{7}{|c|}{ Results Obtained in Greenhouses (b) } \\
\hline & Control & $2.6 \pm 0.38 c$ & $2.9 \pm 0.19 c$ & $2.7 \pm 0.11 \mathrm{c}$ & 2.7 & 5.59 \\
\hline & Zinc & $3.3 \pm 0.56 b$ & $3.3 \pm 0.11 b$ & $3.8 \pm 0.55 \mathrm{a}$ & 3.5 & 8.33 \\
\hline & Boron & $3.6 \pm 0.13 \mathrm{ab}$ & $3.5 \pm 0.77 \mathrm{~b}$ & $3.2 \pm 0.61 b$ & 3.4 & 6.06 \\
\hline & MIX & $4.3 \pm 0.10 \mathrm{a}$ & $4.0 \pm 0.39 a b$ & $3.7 \pm 0.13 \mathrm{a}$ & 4.0 & 7.50 \\
\hline & Coveron & $4.4 \pm 0.17 \mathrm{a}$ & $4.4 \pm 0.46 \mathrm{a}$ & $3.9 \pm 0.52 \mathrm{a}$ & 4.2 & 6.82 \\
\hline & Average & 3.6 & 3.6 & 3.5 & - & - \\
\hline & $\mathrm{CV} \%$ & 20.4 & 16.3 & 14.5 & - & - \\
\hline
\end{tabular}

Tukey's multiple range test, significant effect $p \leq 0.05$, different small letters, $\mathrm{a}, \mathrm{b} \ldots \mathrm{x}$, values are mean \pm standard error of the mean, Coveron - (commercial product consisting of Trichoderma atroviride, Glomus mosseae, Glomus intraradices), MIX - (zinc $\mathrm{ZnSO}_{4}+\mathrm{boron}$ $0.025 \%+$ biological product - Coveron).

On the other hand, the root length of seedlings in the greenhouse ranged from $2.7 \mathrm{~cm}$ (control) to $4.2 \mathrm{~cm}$ (Coveron treatment). The greatest variation in the expression of this trait was recorded when $\mathrm{Zn}$ was applied (CV8.33\%), and the highest effect of the cultivar on the root length variation was observed in cultivar Cezar (Table $7 \mathrm{~b}$ ).

The difference between the control and the $\mathrm{Zn}$ treatment was not statistically significant $(p \geq 0.05)$ for the root length for cultivars Omega and Cezar, and between the control and the MIX treatment for cultivar Omega in the greenhouse (Table 8).

Table 8. Factors on germination and the seedling growth after treatments applied to celeriac cultivars.

\begin{tabular}{|c|c|c|c|}
\hline \multicolumn{4}{|c|}{ Results Obtained in Germination Cabinets (F-Test) } \\
\hline Source & Cezar & Omega & Praški krupni \\
\hline Cultivar (A) & * & * & * \\
\hline Treatment (B) & $* *$ & * & * \\
\hline Location $(\mathrm{C})$ & ns & ns & ns \\
\hline Year (D) & ns & ns & ns \\
\hline$A \times B$ & * & * & * \\
\hline $\mathrm{A} \times \mathrm{C}$ & ns & ns & ns \\
\hline$A \times D$ & $\mathrm{~ns}$ & ns & ns \\
\hline$B \times C$ & ns & ns & ns \\
\hline$B \times D$ & ns & ns & ns \\
\hline $\mathrm{C} \times \mathrm{D}$ & ns & ns & ns \\
\hline \multicolumn{4}{|c|}{ Results Obtained in Greenhouses (F-Test) } \\
\hline Cultivar (A) & $*$ & * & * \\
\hline Treatment (B) & ** & * & * \\
\hline Location (C) & ns & ns & ns \\
\hline Year (D) & ns & ns & $\mathrm{ns}$ \\
\hline$A \times B$ & $*$ & $*$ & $*$ \\
\hline $\mathrm{A} \times \mathrm{C}$ & ns & ns & ns \\
\hline$A \times D$ & ns & ns & ns \\
\hline$B \times C$ & ns & ns & $\mathrm{ns}$ \\
\hline $\mathrm{B} \times \mathrm{D}$ & ns & ns & ns \\
\hline$C \times D$ & ns & ns & ns \\
\hline
\end{tabular}

Significancy of the F tests at the: ${ }^{*} p \leq 0.05,{ }^{* *} p \leq 0.01$; ns-not significant $(p \geq 0.05)$; interaction of factors: cultivar $\times$ treatment $(A \times B)$, cultivar $\times$ location $(A \times C)$, cultivar $\times$ year $(A \times D)$, treatment $\times$ location $(B \times C)$, teratment $\times$ year $(B \times D)$, location $\times$ year $(C \times D)$. 
The PCA was applied to the celeriac seeds and the first and the second principal components (PC-1 and PC-2) accounted for $52.48 \%$ and $35.49 \%$, respectively, of the total data variance, i.e., their mutual projections (Figure 2). This analysis also confirmed that the treatments and cultivars were correlated and classified into the same group, A1 and A2, except for the treatments in cultivar Cezar (CE), while on the other hand, control treatments were in the second group (B1 and B2) (Figure 2).

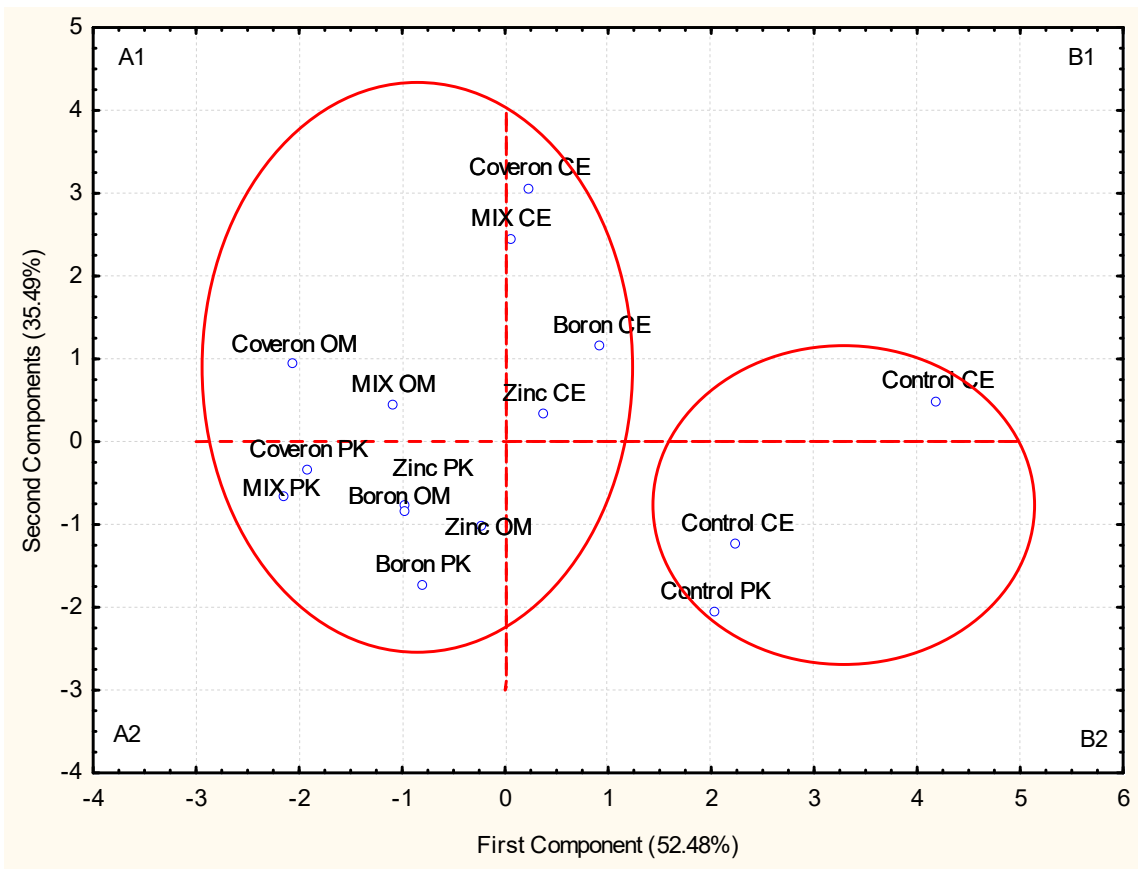

Figure 2. Principal component analysis (PCA) for the treatment effect on germination seed and on embryonic stem and radicle (Apium graveolens L.), C-Cezar, OM-Omega, PK-Praški krupni.

\subsection{Wheat Seed}

2.3.1. Effects of Factors: Years (Y)/Cultivars (C)/Trichoderma harzianum, Bacillus spp. and Treatment (T)

Effects of the year, and the $\mathrm{Y} \times \mathrm{C}$ interaction and $\mathrm{Y} \times \mathrm{T}$ interaction were not significant $(p \geq 0.05)$, values presented are the two-year averages. Effects of the factors cultivar and treatments, as well as their interaction on all examined traits were significant $(p \leq 0.05$ to $p \leq 0.01$ ) (Table 9).

Table 9. ANOVA for assess the influence of year, cultivar and treatment on the tested features: germination (\%), Fusarium sp. (\%), Alternaria sp. (\%), Penicillium sp. (\%), Mucor sp. (\%), shoot, and root length $(\mathrm{cm})$.

\begin{tabular}{cccccccc}
\hline & \multicolumn{7}{c}{ Feature } \\
\cline { 2 - 8 } Factor & G & F & A & $P$ & M & SL & RL \\
\hline D & ns & ns & ns & ns & ns & ns & ns \\
A & $*$ & $* *$ & $* *$ & $* *$ & $* *$ & $*$ & $*$ \\
B & $* * *$ & $* * *$ & $* * *$ & $* * *$ & $* * *$ & $*$ & $*$ \\
$\mathrm{D} \times$ B & ns & ns & ns & ns & ns & ns & ns \\
$\mathrm{D} \times \mathrm{A}$ & $\mathrm{ns}$ & $\mathrm{ns}$ & $\mathrm{ns}$ & $\mathrm{ns}$ & $\mathrm{ns}$ & $\mathrm{ns}$ & $\mathrm{ns}$ \\
$\mathrm{A} \times \mathrm{B}$ & $*$ & $*$ & $*$ & $* *$ & $* *$ & $*$ & $*$
\end{tabular}

Significancy of the F tests at the: ${ }^{*} p \leq 0.05,{ }^{* *} p \leq 0.01,{ }^{* * *} p \leq 0.001 ;$ ns-not significant $(p \geq 0.05)$; G-germination (G); F-Fusarium sp. (\%); A-Alternaria sp. (\%); P-Penicillium sp. (\%); M-Mucor sp. (\%); SL-shoot length and RL-root length $(\mathrm{cm})$. D-year, A-cultivar, B-treatment, Interaction of factor: year $\times$ treatment $(\mathrm{D} \times \mathrm{B})$, year $\times$ cultivar $(\mathrm{D} \times \mathrm{A})$, cultivar $\times$ treatment $(\mathrm{A} \times \mathrm{B})$. 


\subsubsection{Germination}

In general, in all the examined cultivars, T. harzianum seed treatments showed the highest efficiency on seed germination, which was statistically significantly higher compared to the control (Table 10). Using T. harzianum the improvement of germination of wheat seeds ranged from $4 \%$ to $8 \%$ and mostly depended on the wheat cultivar. In addition to the treatment with $T$. harzianum, similar efficiency in increasing germination but with a slightly lower level of significance $(p \leq 0.05)$ was shown by the Bacillus isolate B5 in all three wheat cultivars, as well as isolates B7 and B8 in Salazar and Zemunska rosa, respectively (Table 10). On the other hand, between the treatment with T. harzianum and Bacillus isolates B1, B2, and B4, a significant difference was found in germination in the cultivar Apicol $(p \leq 0.05)$.

Table 10. Influence of Trichoderma harzianum isolate and eight different isolates of Bacillus spp. to influence germination, seedling growth, and the presence of some plant-pathogenic fungi (Fusarium sp., Alternaria sp., Penicillium sp., and Mucor sp.), seed germination, and initial seedling growth (primary shoot and root length) on seeds of three wheat cultivars.

\begin{tabular}{|c|c|c|c|c|c|c|c|c|}
\hline $\mathrm{C}$ & Treatment & $\mathbf{F}$ & $\mathbf{A}$ & $\mathbf{P}$ & $\mathbf{M}$ & G & SL & RL \\
\hline \multirow{10}{*}{$\begin{array}{l}\overline{0} \\
.0 \\
\frac{0}{4}\end{array}$} & Control & $4 \pm 0.96 b$ & $4 \pm 0.00 \mathrm{a}$ & $1 \pm 0.58 \mathrm{a}$ & $1 \pm 0.00 \mathrm{ab}$ & $86 \pm 0.48 b$ & $6.01 \pm 0.31 b$ & $10.6 \pm 0.95 b$ \\
\hline & $\begin{array}{l}\text { Trichoderma } \\
\text { harzianum }\end{array}$ & $1 \pm 0.58 c$ & $1 \pm 0.58 b$ & $0 \pm 0.00 \mathrm{~b}$ & $0 \pm 0.00 \mathrm{~b}$ & $90 \pm 0.29 a$ & $7.56 \pm 0.33 \mathrm{a}$ & $13.4 \pm 0.66 \mathrm{a}$ \\
\hline & Bacillus 1 & $4 \pm 0.96 b$ & $3 \pm 0.58 \mathrm{ab}$ & $0 \pm 0.50 \mathrm{~b}$ & $0 \pm 0.50 \mathrm{~b}$ & $83 \pm 0.31 b$ & $6.03 \pm 0.81 b$ & $11.1 \pm 0.75 \mathrm{ab}$ \\
\hline & Bacillus 2 & $4 \pm 0.82 b$ & $3 \pm 0.82 \mathrm{ab}$ & $0 \pm 0.00 \mathrm{~b}$ & $0 \pm 0.00 \mathrm{~b}$ & $86 \pm 0.19 b$ & $6.52 \pm 0.48 \mathrm{ab}$ & $11.4 \pm 0.89 \mathrm{ab}$ \\
\hline & Bacillus 3 & $2 \pm 0.96 c$ & $2 \pm 0.96 \mathrm{~b}$ & $1 \pm 0.00 \mathrm{a}$ & $1 \pm 0.58 \mathrm{ab}$ & $87 \pm 0.18 \mathrm{ab}$ & $6.67 \pm 0.51 \mathrm{ab}$ & $11.2 \pm 0.88 \mathrm{ab}$ \\
\hline & Bacillus 4 & $4 \pm 0.96 \mathrm{~b}$ & $4 \pm 0.82 \mathrm{a}$ & $0 \pm 0.50 \mathrm{~b}$ & $0 \pm 0.00 \mathrm{~b}$ & $85 \pm 0.09 \mathrm{~b}$ & $6.56 \pm 0.67 \mathrm{ab}$ & $10.8 \pm 0.81 b$ \\
\hline & Bacillus 5 & $5 \pm 0.78 \mathrm{ab}$ & $2 \pm 0.96 \mathrm{~b}$ & $0 \pm 0.00 \mathrm{~b}$ & $0 \pm 0.00 \mathrm{~b}$ & $90 \pm 0.22 \mathrm{a}$ & $7.52 \pm 0.51 \mathrm{a}$ & $12.8 \pm 0.55 \mathrm{a}$ \\
\hline & Bacillus 6 & $6 \pm 0.65 a$ & $4 \pm 0.50 \mathrm{a}$ & $0 \pm 0.00 \mathrm{~b}$ & $2 \pm 0.96 \mathrm{a}$ & $88 \pm 0.36 \mathrm{ab}$ & $6.99 \pm 0.80 \mathrm{ab}$ & $11.9 \pm 0.46 \mathrm{ab}$ \\
\hline & Bacillus 7 & $3 \pm 0.82 b c$ & $4 \pm 0.50 \mathrm{a}$ & $0 \pm 0.50 \mathrm{~b}$ & $3 \pm 0.58 \mathrm{a}$ & $88 \pm 0.21 \mathrm{ab}$ & $7.03 \pm 0.71 \mathrm{a}$ & $12.6 \pm 0.81 \mathrm{a}$ \\
\hline & Bacillus 8 & $4 \pm 0.00 \mathrm{~b}$ & $3 \pm 0.58 \mathrm{ab}$ & $1 \pm 0.58 \mathrm{a}$ & $1 \pm 0.58 \mathrm{ab}$ & $87 \pm 0.36 \mathrm{ab}$ & $6.98 \pm 0.55 a$ & $12.9 \pm 0.92 \mathrm{a}$ \\
\hline \multirow{10}{*}{$\begin{array}{l}\text { సี } \\
\text { तै } \\
\text { స్ }\end{array}$} & Control & $4 \pm 0.96 \mathrm{~b}$ & $3 \pm 0.00 \mathrm{ab}$ & $0 \pm 0.00 \mathrm{~b}$ & $0 \pm 0.00 \mathrm{~b}$ & $83 \pm 0.26 c$ & $6.06 \pm 0.52 b$ & $10.1 \pm 0.86 \mathrm{~b}$ \\
\hline & $\begin{array}{l}\text { Trichoderma } \\
\text { harziaum }\end{array}$ & $1 \pm 0.58 c$ & $1 \pm 0.00 \mathrm{~b}$ & $0 \pm 0.00 \mathrm{~b}$ & $0 \pm 0.00 \mathrm{~b}$ & $91 \pm 0.26 \mathrm{a}$ & $7.77 \pm 0.44 \mathrm{a}$ & $13.7 \pm 0.38 \mathrm{a}$ \\
\hline & Bacillus 1 & $5 \pm 0.29 \mathrm{ab}$ & $1 \pm 0.58 b$ & $0 \pm 0.00 \mathrm{~b}$ & $0 \pm 0.00 \mathrm{~b}$ & $85 \pm 0.38 b c$ & $6.65 \pm 0.55 \mathrm{ab}$ & $11.2 \pm 1.08 \mathrm{ab}$ \\
\hline & Bacillus 2 & $2 \pm 0.00 c$ & $2 \pm 0.00 \mathrm{~b}$ & $0 \pm 0.00 \mathrm{~b}$ & $0 \pm 0.00 \mathrm{~b}$ & $86 \pm 0.22 b$ & $6.72 \pm 031 \mathrm{ab}$ & $11.5 \pm 0.55 \mathrm{ab}$ \\
\hline & Bacillus 3 & $3 \pm 0.82 b c$ & $3 \pm 0.58 \mathrm{ab}$ & $0 \pm 0.50 \mathrm{~b}$ & $1 \pm 0.00 \mathrm{ab}$ & $85 \pm 0.26 b c$ & $6.69 \pm 0.48 \mathrm{ab}$ & $10.9 \pm 0.28 \mathrm{ab}$ \\
\hline & Bacillus 4 & $3 \pm 0.82 b c$ & $3 \pm 0.58 \mathrm{ab}$ & $1 \pm 0.00 \mathrm{a}$ & $0 \pm 0.50 \mathrm{~b}$ & $86 \pm 0.38 b$ & $6.71 \pm 0.68 \mathrm{ab}$ & $11.7 \pm 0.77 \mathrm{ab}$ \\
\hline & Bacillus 5 & $2 \pm 0.96 c$ & $4 \pm 0.00 \mathrm{a}$ & $0 \pm 0.00 \mathrm{~b}$ & $0 \pm 0.00 \mathrm{~b}$ & $89 \pm 0.17 \mathrm{ab}$ & $7.21 \pm 0.78 \mathrm{a}$ & $12.9 \pm 0.81 \mathrm{a}$ \\
\hline & Bacillus 6 & $4 \pm 0.82 \mathrm{~b}$ & $4 \pm 0.96 \mathrm{a}$ & $0 \pm 0.50 \mathrm{~b}$ & $2 \pm 0.00 \mathrm{a}$ & $86 \pm 0.32 \mathrm{~b}$ & $6.66 \pm 0.66 \mathrm{ab}$ & $10.4 \pm 0.89 \mathrm{~b}$ \\
\hline & Bacillus 7 & $6 \pm 0.46 \mathrm{a}$ & $4 \pm 0.82 \mathrm{a}$ & $0 \pm 0.50 \mathrm{~b}$ & $0 \pm 0.00 \mathrm{~b}$ & $90 \pm 0.24 \mathrm{a}$ & $7.71 \pm 0.51 \mathrm{a}$ & $13.3 \pm 0.98 \mathrm{a}$ \\
\hline & Bacillus 8 & $3 \pm 0.00 \mathrm{bc}$ & $1 \pm 0.58 b$ & $1 \pm 0.58 \mathrm{a}$ & $0 \pm 0.00 \mathrm{~b}$ & $90 \pm 0.22 \mathrm{a}$ & $7.68 \pm 0.63 a$ & $13.2 \pm 0.75 \mathrm{a}$ \\
\hline \multirow{10}{*}{ 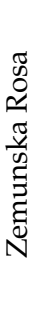 } & Control & $4 \pm 0.96 \mathrm{a}$ & $4 \pm 0.96 \mathrm{a}$ & $1 \pm 0.58 \mathrm{a}$ & $1 \pm 0.00 \mathrm{ab}$ & $85 \pm 0.32 c$ & $5.59 \pm 0.67 b$ & $10.3 \pm 0.62 b$ \\
\hline & $\begin{array}{l}\text { Trichoderma } \\
\text { harzianum }\end{array}$ & $1 \pm 0.00 \mathrm{c}$ & $1 \pm 0.00 \mathrm{~b}$ & $0 \pm 0.00 \mathrm{~b}$ & $0 \pm 0.00 \mathrm{~b}$ & $89 \pm 0.41 \mathrm{a}$ & $7.59 \pm 0.28 \mathrm{a}$ & $14.1 \pm 0.46 \mathrm{a}$ \\
\hline & Bacillus 1 & $4 \pm 0.96 a$ & $2 \pm 0.00 \mathrm{~b}$ & $0 \pm 0.00 \mathrm{~b}$ & $0 \pm 0.00 \mathrm{~b}$ & $86 \pm 0.32 b c$ & $6.35 \pm 0.31 \mathrm{ab}$ & $11.3 \pm 0.35 \mathrm{ab}$ \\
\hline & Bacillus 2 & $3 \pm 0.82 \mathrm{ab}$ & $4 \pm 0.50 \mathrm{a}$ & $0 \pm 0.50 \mathrm{~b}$ & $0 \pm 0.00 \mathrm{~b}$ & $88 \pm 0.26 \mathrm{ab}$ & $7.55 \pm 0.52 \mathrm{ab}$ & $11.7 \pm 0.68 \mathrm{ab}$ \\
\hline & Bacillus 3 & $4 \pm 0.00 \mathrm{a}$ & $2 \pm 0.96 \mathrm{~b}$ & $0 \pm 0.00 \mathrm{~b}$ & $0 \pm 0.00 \mathrm{~b}$ & $85 \pm 0.31 c$ & $6.08 \pm 0.83 b$ & $11.1 \pm 0.70 \mathrm{ab}$ \\
\hline & Bacillus 4 & $2 \pm 0.96 \mathrm{~b}$ & $3 \pm 0.58 \mathrm{ab}$ & $0 \pm 0.00 \mathrm{~b}$ & $0 \pm 0.50 \mathrm{~b}$ & $87 \pm 0.36 \mathrm{~b}$ & $6.62 \pm 0.74 \mathrm{ab}$ & $11.8 \pm 0.68 \mathrm{ab}$ \\
\hline & Bacillus 5 & $3 \pm 0.82 \mathrm{ab}$ & $1 \pm 0.58 \mathrm{~b}$ & $0 \pm 0.50 \mathrm{~b}$ & $0 \pm 0.50 \mathrm{~b}$ & $88 \pm 0.48 \mathrm{ab}$ & $7.58 \pm 0.51 \mathrm{a}$ & $13.5 \pm 0.87 \mathrm{a}$ \\
\hline & Bacillus 6 & $4 \pm 0.96 \mathrm{a}$ & $3 \pm 0.82 \mathrm{ab}$ & $0 \pm 0.00 \mathrm{~b}$ & $1 \pm 0.58 \mathrm{ab}$ & $86 \pm 0.31 b c$ & $6.59 \pm 0.43 \mathrm{ab}$ & $10.6 \pm 0.53 b$ \\
\hline & Bacillus 7 & $3 \pm 0.00 \mathrm{ab}$ & $2 \pm 0.96 \mathrm{~b}$ & $0 \pm 0.00 \mathrm{~b}$ & $0 \pm 0.00 \mathrm{~b}$ & $89 \pm 0.17 \mathrm{a}$ & $7.62 \pm 0.49 \mathrm{a}$ & $13.6 \pm 0.88 a$ \\
\hline & Bacillus 8 & $4 \pm 0.82 \mathrm{a}$ & $1 \pm 0.00 \mathrm{~b}$ & $0 \pm 0.50 \mathrm{~b}$ & $0 \pm 0.00 \mathrm{~b}$ & $88 \pm 0.21 \mathrm{ab}$ & $7.53 \pm 0.82 \mathrm{a}$ & $13.4 \pm 0.81 \mathrm{a}$ \\
\hline
\end{tabular}

C-cultivar; Tukey test-significance level $p \leq 0.05$, different small letters, $\mathrm{a}, \mathrm{b} \ldots \mathrm{x}$, values are mean \pm standard error of the mean; was used to assess the mean treatment, for each cultivar separately; F-Fusarium sp. (\%); A-Alternaria sp. (\%); P-Penicillium sp. (\%); M-Mucor sp. $(\%) ; \mathrm{G}-$ germination (\%); SL-shoot length and RL-root length (cm).

In the cultivar Salazar, a significant difference was found between the effects of T. harzianum and Bacillus isolates B2, B4, and B6. In the cultivar Zemunska rosa, a significant difference was found between T. harzianum and Bacillus isolates B1, B3, B4, and B6. The examined treatments had an increase in germination by $4 \%$, compared to the control in the cultivars Apicol (treatments T. harzianum and B5) and Zemunska rosa (treatments T. harzianum and B7). In comparison to the control, the applied treatments affected the increase in germination by $4 \%$ in the cultivars Apicol (treatments T. harzianum and B5) and Zemunska rosa (treatments T. harzianum and B7). The largest increase of $8 \%$ was found in cultivar Salazar after the treatment with T. harzianum (Table 10). 
Therefore, the differences in germination promoting effects could be attributed to the specific association released between individual wheat cultivar and particular Trichoderma strain. Similarly, four various Trichoderma strains applied in wheat BRS 264 displayed different promoting potential ranging from 3\% to 8\%, while T. harzianum ESALQ 1306 provided the best results regarding germination and seedling performances under greenhouse conditions [48]. Trichoderma may improve germination by increasing the synthesis of endogenous plant growth regulators by up-regulation of genes for their synthesis and by down-regulation of genes included in their catabolism [49]. Since gibberellic acid (GA3) can improve seed germination by promotion of activity on hydrolytic and proteolytic enzymes that act to mobilize the food reserves from the cotyledons or endosperm, at least one of the promotive effect of T. harzianum IS005-12 on wheat seeds germination is attributed to increasing of GA3 level. In cherry rootstocks T. harzianum strain T22 increased the content of GA3 in leaves by $71 \%$ and in roots even by $143 \%$ [50]. Harman et al. [51] reported that treatment of soybean seeds by conidia of T. harzianum T22 enhanced phase III imbibitions (cell elongation, followed by radicle protrusion). Roots of these seeds were larger and more robust as evidenced in soybean plants in which an increase of $123 \%$ in yield was obtained when inoculated with T-22 [51]. Furthermore, Hoyos-Carvajal et al. [52] reported beneficial effects on germination and seedling emergence, since the solubilized nutrients become more available for root uptake [52].

Species of the genus Trichoderma have developed several mechanisms that con-tributed to increasing plant resistance to diseases, growth and development, and root morphology, as well as seed germination [53,54]. The plant growth promotion by Trichoderma has been observed in many crops. The present study shows the results of seed treatments of three wheat cultivars with T. harzianum. The results indicated a positive effect of this saprophytic fungus on seed germination and the seedling growth. According to Gravel et al. [55], Trichoderma spp. produced indole-3-acetic acid (IAA), which physiologically affected the elongation and the growth of cells, and as a result stimulated the accelerated growth of tomato seedlings. The T. harzianum-based biological preparation (Ecotrich WP) showed similar effects on the development of soya bean roots [56], which is consistent with and explains our results on seed germination and the initial seedling growth of lettuce and celeriac (Tables 1 and 2). Trichoderma spp. when absorbed by seeds of wheat and Italian ryegrass promoted germination, the initial seedling growth, resistance of newly emerged seedlings to diseases caused by pathogens [54,57]. However, mechanisms of action of Trichoderma strains are influenced by genetic variability of Trichoderma, genetic variability of the plant species whose seeds are treated as well as their interactions. Therefore, whether effects will be positive or negative are unpredictable [14,54].

Wheat seed study, the impact of the year was not significant (Table 9) on properties of wheat seeds, this is probably because both years were similar in terms of climatic conditions in which production took place (not shown). Studies of wheat seeds show that the impact of the year was not significant (Table 9) on the wheat seed properties. This is probably because both years were similar with regard to weather conditions under which production was performed. It is recommended that the wheat production in the world is carried out with the reduced use of pesticides or without their use $[15,53,58,59]$. These measures reduce the risk of negative effects of wheat products on human health $[24,58]$. Bacteria that produce extracellular antifungal compounds that indirectly stimulate the self-defense system of the host plant are capable of acting antagonistically on pathogens. Because of this action, they are ideal for biological control [60]. According to Ji et al. [15], organic cereal production methods result in significantly lower pesticide residues in wheat flour. The positive effect of T. harzianum treatment on the wheat primary root was obvious as its length increased by $2.8-3.8 \mathrm{~cm}$ depending on the cultivar. In addition to the direct effect on seed germination, some species of Trichoderma have a biocontrol effect and are used as biopesticides against fungal plant diseases [61]. The increase in soya bean seed germination by up to $20 \%$ was established after the treatment with six different species of Trichoderma had been applied [62]. 


\subsubsection{Seedling Infection and Growth}

The seed treatment with $T$. harzianum showed the highest efficacy in reducing seedling infection with the pathogens of the genera Fusarium, Alternaria, Penicillium, and Mucor. Thus, in all tested cultivars, percentages of infected seedlings with Fusarium sp. and Alternaria sp. was $1 \%$ compared to the control that amounted to $4 \%$ and 3-4\%, respectively, while the presence of Penicillium sp. and Mucor sp. was not detected in the treated seedlings (Table 4). The highest increase in the seedling length occurred when seeds were treated with T. harzianum and Bacillus isolates B5, B7, and B8 (Table 10).

\subsubsection{Correlation, PCA, and Cluster Analysis}

In all wheat cultivars a negative but not significant $(p \geq 0.05)$ correlation between germination and the presence of examined pathogens was found (Table 11). Only in the cultivar Zemunska rosa, the correlation between germination and the presence of Fusarium sp. was significant $(p \leq 0.05)$ and negative $(r=-0.649)$. Furthermore, a negative, but not significant correlation $(p \geq 0.05)$ was detected between the seedling growth (which includes the growth of primary roots and shoots), and the presence of the examined pathogens in all wheat cultivars. Contrarily, the highest $(p \leq 0.001)$ and positive dependence was established between seed germination and the primary shoot length in all tested cultivars $(r=0.911-0.983)$. The same applies to the correlation between germination and the primary root length in cultivars Salazar $(r=0.960)$ and Zemunska rosa $(r=0.903)$, while a correlation of a lower significance was obtained in the cultivar Apicol $(r=0.785)$. A positive correlation at the highest significance level $(p \leq 0.001)$ was determined between the shoot length and the root length in the cultivars Apicol $(\mathrm{r}=0.893)$ and Salazar $(\mathrm{r}=0.955)$, while in the cultivar Zemunska rosa it was at the lower significance level $(r=0.863)$ (Table 11).

Table 11. Correlation dependence $(r)$ between the germination and other examined parameters in three wheat cultivars $(n=10)$.

\begin{tabular}{|c|c|c|c|c|c|c|c|}
\hline Cultivar & Examined Feature & $\mathbf{F}$ & $\mathbf{A}$ & $\mathbf{P}$ & $\mathbf{M}$ & PSL & PRL \\
\hline 㝨 & $\begin{array}{l}\text { Germination } \\
\text { Fusarium sp. } \\
\text { Aternaria } \mathrm{sp} \text {. } \\
\text { Penicillium } \mathrm{sp} \text {. } \\
\text { Mucor sp. } \\
\text { Primary shoot length }\end{array}$ & $\begin{array}{c}-0.181 \mathrm{~ns} \\
-\end{array}$ & $\begin{array}{c}-0.488 \mathrm{~ns} \\
0.595 \mathrm{~ns} \\
-\end{array}$ & $\begin{array}{c}-0.106 \mathrm{~ns} \\
-0.178 \mathrm{~ns} \\
0.000 \mathrm{~ns} \\
-\end{array}$ & $\begin{array}{c}-0.199 \mathrm{~ns} \\
0.106 \mathrm{~ns} \\
0.510 \mathrm{~ns} \\
0.134 \mathrm{~ns} \\
-\end{array}$ & $\begin{array}{l}0.911^{* * *} \\
-0.174 \mathrm{~ns} \\
-0.535 \mathrm{~ns} \\
-0.301 \mathrm{~ns} \\
-0.087 \mathrm{~ns} \\
-\end{array}$ & $\begin{array}{c}0.785^{* *} \\
-0.522 \mathrm{~ns} \\
-0.522 \mathrm{~ns} \\
-0.211 \mathrm{~ns} \\
-0.146 \mathrm{~ns} \\
0.893^{* * *}\end{array}$ \\
\hline 胥 & $\begin{array}{l}\text { Germination } \\
\text { Fusarium sp. } \\
\text { Aternaria } \mathrm{sp} \text {. } \\
\text { Penicillium } \mathrm{sp} \text {. } \\
\text { Mucor sp. } \\
\text { Primary shoot length }\end{array}$ & $\begin{array}{c}-0.257 \mathrm{~ns} \\
-\end{array}$ & $\begin{array}{c}-0.150 \mathrm{~ns} \\
0.306 \mathrm{~ns} \\
-\end{array}$ & $\begin{array}{c}-0.177 \mathrm{~ns} \\
-0.106 \mathrm{~ns} \\
-0.250 \mathrm{~ns} \\
-\end{array}$ & $\begin{array}{c}-0.264 \mathrm{~ns} \\
0.121 \mathrm{~ns} \\
0.416 \mathrm{~ns} \\
-0.234 \mathrm{~ns} \\
-\end{array}$ & $\begin{array}{c}0.983^{* * *} \\
-0.165 \mathrm{~ns} \\
-0.213 \mathrm{~ns} \\
0.191 \mathrm{~ns} \\
-0.271 \mathrm{~ns} \\
-\end{array}$ & $\begin{array}{c}0.960 * * * \\
-0.268 \mathrm{~ns} \\
-0.240 \mathrm{~ns} \\
0.228 \mathrm{~ns} \\
-0.505 \mathrm{~ns} \\
0.955^{* * *}\end{array}$ \\
\hline 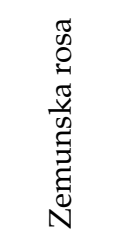 & $\begin{array}{l}\text { Germination } \\
\text { Fusarium } \mathrm{sp} . \\
\text { Aternaria sp. } \\
\text { Penicillium } \mathrm{sp} \text {. } \\
\text { Mucor sp. } \\
\text { Primary shoot length }\end{array}$ & $\begin{array}{c}-0.649 * \\
-\end{array}$ & $\begin{array}{c}-0.459 \mathrm{~ns} \\
0.223 \mathrm{~ns} \\
-\end{array}$ & $\begin{array}{c}-0.484 \mathrm{~ns} \\
0.272 \mathrm{~ns} \\
0.515 \mathrm{~ns} \\
-\end{array}$ & $\begin{array}{c}-0.553 \mathrm{~ns} \\
0.408 \mathrm{~ns} \\
0.545 \mathrm{~ns} \\
0.667^{*} \\
-\end{array}$ & $\begin{array}{c}0.954^{* * *} \\
-0.495 \mathrm{~ns} \\
-0.500 \mathrm{~ns} \\
-0.614 \mathrm{~ns} \\
-0.572 \mathrm{~ns} \\
-\end{array}$ & $\begin{array}{l}0.903^{* * *} \\
-0.589 \mathrm{~ns} \\
-0.562 \mathrm{~ns} \\
-0.467 \mathrm{~ns} \\
-0.643^{*} \\
0.863^{* *}\end{array}$ \\
\hline
\end{tabular}

${ }^{*} p \leq 0.05,{ }^{* *} p \leq 0.01,{ }^{* * *} p \leq 0.001$, ns-not significant ( $\left.p \geq 0.05\right) ; \mathrm{F}-$ Fusarium sp.; A-Alternaria sp.; P—Penicillium sp.; $\mathrm{M}-$ Mucor sp.; PSL-primary shoot length; PRL—primary root length.

Based on the examined effects of the treatments applied to three wheat cultivars and their effects on germination, presence of fungal pathogens and the shoot and the root length, the cluster analysis clearly singed out the impact of $T$. harzianum on all three examined cultivars. Treatments with Bacillus isolates (Figures 3 and 4) affected cultivars Zemunska rosa (B5, B7 and B8) and Salazar (B8). The PCA confirmed that treatments with T. harzianum and Bacillus isolates B8, B5, and B7 were classified in the same group-A1 (Figures 3 and 4). 
Treatments with B3 and B4 applied in to the cultivars Apicol and Zemunska rosa were also classified in the same group but closer to the border with the group B1.

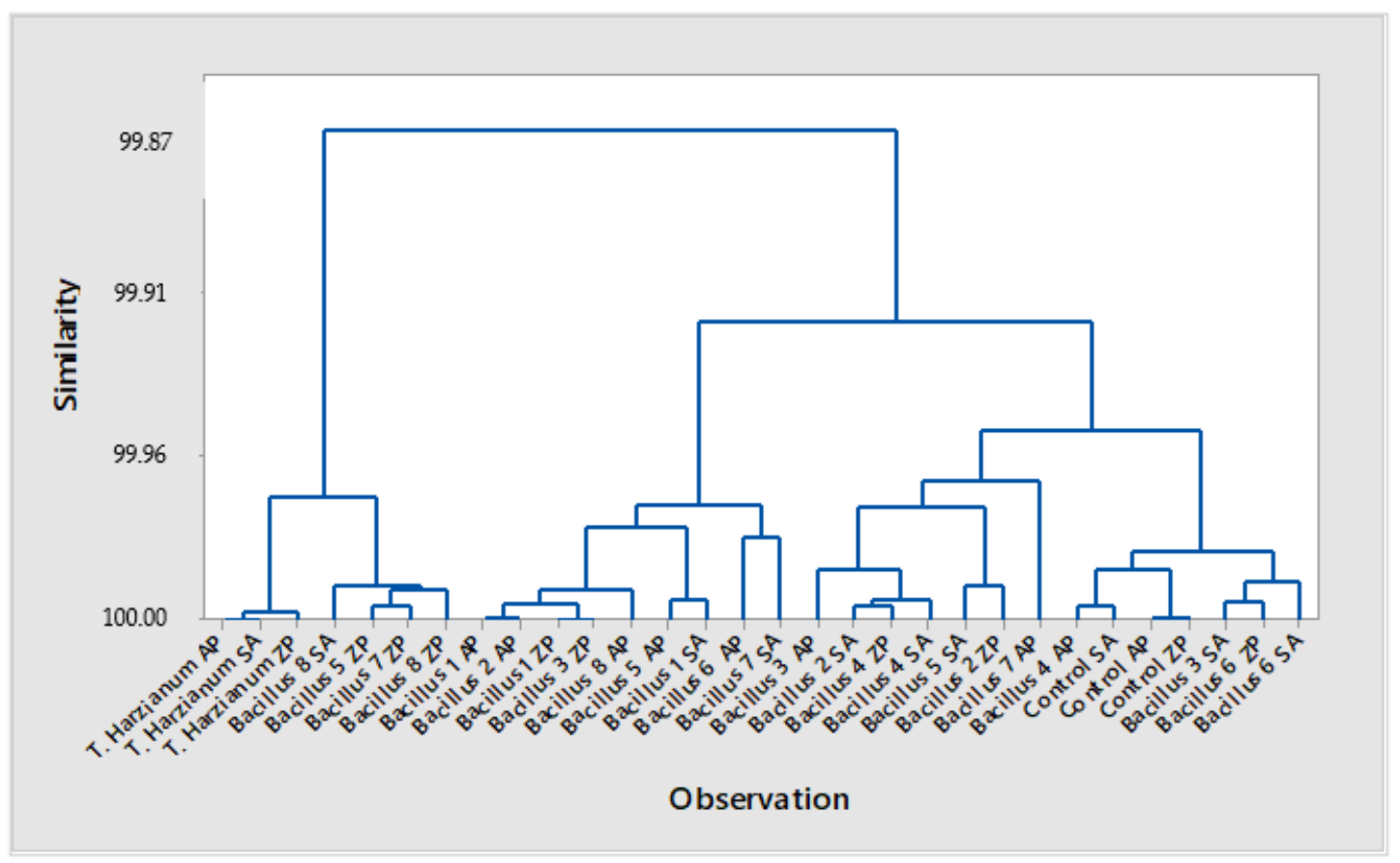

Figure 3. Cluster analysis for the treatment effect on germination, presence of fungal species Fusarium sp., Alternaria sp., Penicillium sp., Mucor sp., and on the shoot and root length, AP-Apicol, SA-Salazar, ZP-Zemunska rosa.

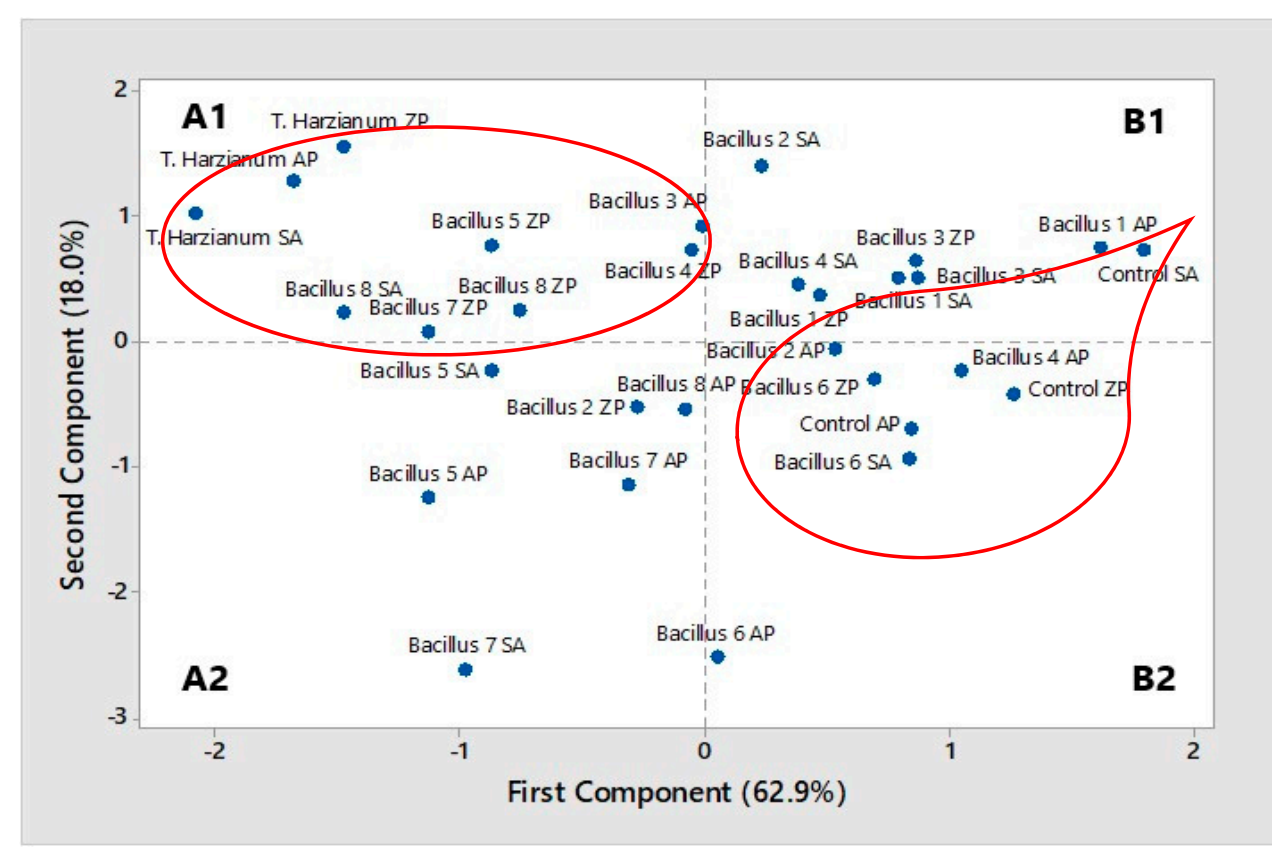

Figure 4. Principal component analysis (PCA) for the treatment effect on germination presence of fungi (Fusarium sp., Alternaria sp., Penicillium sp., Mucor sp.) and the shoot and root length, $\mathrm{AP}$-Apicol, SA-Salazar, ZP-Zemunska rosa.

\section{Materials and Methods}

\subsection{Plant Material}

The following cultivars (factor A) of lettuce (Lactuca sativa L.): (i) Genius, (ii) Majska kraljica, (iii) Endivia, celeriac (Apium graveolens L.): (i) Cezar, (ii) Omega, (iii) Praški krupni 
and wheat (Triticum aestivum L.): (i) Apicol, (ii) Salazar and (iii) Zemunska rosa were used in the study.

Studies with lettuce and celeriac were performed in two locations (factor C): the Seed Testing Laboratory in Topčider (with the germination cabinet and a greenhouse) (C1) and the Seed Testing Laboratory in Batajnica (with the germination cabinet and a greenhouse) (C2). Studies with wheat were performed in the Laboratory for Testing the Quality of Seeds and Planting Material of the Institute for Plant Protection and the Environment with germination cabinet during the trial was carried out according to the same procedure for two years, 2018-2019 (factor D).

The following parameters were observed in the study: seed germination, the shoot, and root length.

\subsection{Preparation of Plant Material to Germination}

In the germination cabinet, lettuce, celeriac, and wheat seeds were sown in boxes (size: $20 \mathrm{~cm}(\mathrm{~L}), 14 \mathrm{~cm}(\mathrm{~W})$, and $4 \mathrm{~cm}(\mathrm{D})$, with sand as a growing medium with the grain size of $0.05-0.8 \mathrm{~mm}, \mathrm{pH} 7$, previously sterilized at $100{ }^{\circ} \mathrm{C}$ for $60 \mathrm{~min}$. The sand moisture was maintained at the optimum level by occasional wetting. Seeds $(4 \times 100)$ were sown for each cultivar within each plant species.

In the greenhouse, lettuce and celeriac seeds were sown in $25 \mathrm{~cm}$ soil-filled pots. Four hundred seeds $(4 \times 100)$ were sown for each cultivar within each plant species.

\subsection{Laboratory Condition of Germination}

Germination cabinets: germination of lettuce seeds was tested at $20^{\circ} \mathrm{C}$, in the dark, for seven days. Germination of celeriac seeds was tested within the temperature regime $20<=>30^{\circ} \mathrm{C}$ (altering temperature regime of $20^{\circ} \mathrm{C}$ for $16 \mathrm{~h}$ in the dark and $30^{\circ} \mathrm{C}$ for $8 \mathrm{~h}$ in the light) for 21 days. Germination of wheat in germination cabinets was tested in the following way: cold test $-5-10{ }^{\circ} \mathrm{C}$ for three days and $20^{\circ} \mathrm{C}$ for eight days in the dark.

In the greenhouse, germination was determined 10 and 30 days after sowing of lettuce and celeriac, respectively.

\subsection{Stress Factors}

There were four treatments (factor B) applied to lettuce and celeriac cultivars and compared to the control (without any treatments: 1$)$ zinc $\left.\left(\mathrm{ZnSO}_{4} 0.5 \%\right), 2\right)$ boron $(0.025 \%)$, 3) biological product - Coveron (commercial product consisting of Trichoderma atroviride, Glomus mosseae, Glomus intraradices), and 4) MIX - (zinc $\mathrm{ZnSO}_{4}+$ boron $0.025 \%+$ biological product - Coveron).

After the 2019 and 2020 wheat harvest, seeds of three wheat cultivars: Apicol, Salazar, and Zemunska rosa were separately treated with the isolate of Trichoderma harzianum and eight isolates of Bacillus spp. (from B1 to B8). Tested seed were treated with a spore

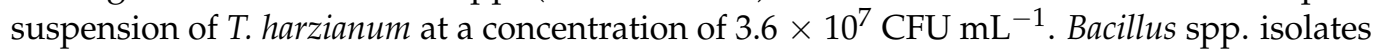
were grown on the Luria-Bertani (LB) medium and incubated at the temperature of $30^{\circ} \mathrm{C}$ for $24 \mathrm{~h}$ and adjusted to a concentration of approximately $10^{8} \mathrm{CFU} \mathrm{mL} \mathrm{L}^{-1}$ [63]. Wheat seeds were soaked in isolates suspensions and kept for a $24 \mathrm{~h}$, after which they were placed on germination according to the ISTA Rules [64] in the Laboratory for Testing the Quality of Seeds and Planting Material of the Institute for Plant Protection and the Environment. The seed control samples were treated with sterile water. Experiments were conducted in four replicates, each containing 100 seeds $(4 \times 100)$. After eight days of the germination test, the germination and the presence of fungal pathogens were evaluated. The presence of the following fungal genera commonly found in non-treated wheat seeds: Fusarium sp., Alternaria sp., Penicillium sp., and Mucor sp. were expressed as the percentage of infected seeds. Plant pathogens were identified based on standard agar plate methods used for detection of seed-borne fungi and morphology observed by light microscopy [64] (ISTA, 2020). The final seedling count was made after 8 days for all three cultivars. Primary root 
length $(\mathrm{cm})$ and the primary shoot length $(\mathrm{cm})$ were measured on healthy seedlings after the final counting. The seedling length was measured using a ruler.

The fungus T. harzianum was isolated in the Mycology Laboratory, Department of Plant Physiology of the Institute for Biological Research Siniša Stanković, Belgrade. Eight bacterial isolates (coded as B1-B8) belonging to the genus Bacillus were isolated from the soil in the Department of Plant Diseases of the Institute for Plant Protection and Environment, Belgrade.

\subsection{Determination of Shoot and Root Length in Laboratory Conditions and Greenhouses}

The shoot and root lengths in germination cabinets were determined on the same day as germination - on the 7th and 21st day for lettuce and celeriac, respectively, and 8th day for wheat, according to the method previously applied in the study carried out by Stanisavljević et al. [65]. In the greenhouses, the length of shoots and roots was determined on the 10th for lettuce and the 30th day for celery, after sowing on the pots, according to the method previously applied in the study by Stanisavljević et al. [65].

\subsection{Statistical Analysis}

The ANOVA (F test) was applied to determine the effect of factors. The Tukey's multiple range test $(p \leq 0.05)$ and the coefficient of variance $(\mathrm{CV} \%)$ were used to test environmental effects. Standard error of the mean was calculated to indicate variation around the mean ( \pm s.e.m.). The Pearson's correlation between germination and other examined parameters was calculated using simple correlation coefficients (r). Arcsine transformation was applied to seed germination data and percentages of infected seed before being subjected to the analysis of variance [66]. Cluster and principal component analysis (PCA) was performed based on comparing the impact of treatments. Acquired experimental data were processed using the freeware software package, R-Statistics [67] and Minitab [68]. Statistical analysis comprehended the three general phases.

\section{Conclusions}

The effect on germination and the initial growth of lettuce and celeriac seedlings treated with $\mathrm{Zn}, \mathrm{B}$, the biological preparation-Coveron, or with the mixture of these three treatments was significantly positive or showed a positive trend compared to the control. The application of the biological preparation Coveron can significantly improve germination and the initial growth of lettuce and celeriac seedlings in organic production. On the other hand, in conventional production of these two species, the great improvement can be achieved by the application of both Coveron and microelements or their mixture with Coveron.

The most pronounced effect of Coveron was on the root growth when seeds of both plant species were grown, after the treatment, in the greenhouse. This especially points out to positive effects after the product was used by farmers.

The significant cultivar $\times$ treatment interaction indicates the possibility of selecting the treatment adequate to each cultivar and achieving an additional effect on improving germination and the seedling growth of both the studied species.

Wheat seed treatments with T. harzianum and isolates of the genus Bacillus can increase germination of wheat seeds by $4 \%$ to $8 \%$, respectively. The maximum germination was $91 \%$ in the cultivar Salazar treated with T. harzianum while the minimum was $83 \%$ in the cultivar Apicol treated with the isolate B1. The relatively high germination in relation to the control confirmed the positive impact of the applied treatments on this seed trait. Seed treatments with T. harzianum and selected Bacillus isolates caused a reduction of plant pathogenic fungi: Fusarium sp., Alternaria sp., Penicillium sp., and Mucor sp., by which a negative correlation between seed germination and the presence of pathogens in all examined wheat cultivars was confirmed. Since plant pests can significantly affect agricultural production, sustainable strategies for disease management are necessary in order to reduce the use of pesticides in agriculture. Due to the positive effects on the seed quality and the seedling 
growth, selected isolates of Bacillus sp. (B5, B7, B8) and especially fungus T. harzianum could be observed as biocontrol agents for control of plant pathogens in the organic system of wheat cultivation. Wheat cultivar $\times$ treatment interaction significantly contributed to improving germination and the seedling growth.

Author Contributions: Conceptualization, D.P. and R.S.; methodology, D.P., T.P., A.Ć., N.T. and N.B.; software, R.S. and N.B.; validation, D.P., N.T. and R.Š.; formal analysis, R.S., A.Ć. and T.P.; investigation, D.P., T.P., A.Ć. and R.Š.; resources, M.T. and R.Š.; data curation, M.T., R.Š., A.Ć. and T.P.; writing—original draft preparation, R.S.; writing—review and editing, T.P., A.Ć., N.B.; visualization, M.T., N.B., N.T.; supervision, M.T.; project administration, N.T. and R.Š.; funding acquisition, N.T. All authors have read and agreed to the published version of the manuscript.

Funding: This research was funded by Ministry of Education, Science and Technological Development, Contract No. 451-03-9/2021-14/200010; 451-03-9/2021-14/200007; 451-03-68/2020-14/200040.

Institutional Review Board Statement: Not applicable.

Informed Consent Statement: Not applicable.

Data Availability Statement: All data are available in manuscript.

Acknowledgments: We thank the Ministry of Education, Science and Technological Development, for the financial support of this research.

Conflicts of Interest: The authors declare no conflict of interest.

\section{References}

1. Shatilov, M.; Razin, A.; Ivanova, M. Analysis of the World Lettuce Market. In IOP Conference Series: Earth and Environmental Science; IOP Publishing: Bristol, UK, 2019; p. 012053.

2. Thomas, J.A.; Vasiliev, M.; Alameh, K. Increasing the yield of Lactuca sativa, L. in glass greenhouses through illumination spectral filtering and fevelopment of an optical thin film filter. Sustainability 2020, 12, 3740. [CrossRef]

3. Sarmanovna, T.Z. Phytochemical study of odorous celery root (Apium graveolens L.) grown in the north caucasus. Pharmacogn. J. 2019, 11, 527-530. [CrossRef]

4. Aćimović, M.G.; Milić, N.B. Perspectives of the Apiaceae hepatoprotective effects-A review. Nat. Prod. Commun. 2017, 12, 309-317. [CrossRef]

5. Farooq, M.; Wahid, A.; Siddique, K.H. Micronutrient application through seed treatments: A review. J. Soil Sci. Plant Nutr. 2012, 12, 125-142. [CrossRef]

6. Tsonev, T.; Cebola Lidon, F.J. Zinc in plants-an overview. Emir. J. Food Agric. (EJFA) 2012, 24, 322-333.

7. Tanaka, M.; Fujiwara, T. Physiological roles and transport mechanisms of boron: Perspectives from plants. Pflugers Arch. 2008, 456, 671-677. [CrossRef] [PubMed]

8. Zin, N.A.; Badaluddin, N.A. Biological functions of Trichoderma spp. for agriculture applications. Ann. Agric. Sci. 2020, 65, 168-178. [CrossRef]

9. Erdinc, C.; Durak, E.D.; Ekincialp, A.; Şensoy, S.; Demir, S. Variations in response of determinate common bean (Phaseolus vulgaris L.) genotypes to arbuscular mycorrhizal fungi (AMF) inoculation. Turk. J. Agric. For. 2017, 41, 1-9. [CrossRef]

10. Pathak, N.; Zaidi, R.K. Fungi associated with wheat seed discolouration and abnormalities in in-vitro study. Agric. Sci. 2013, 4, 516-520.

11. Zafar, M.; Jamal, A.; Tahira, R.; Zakria, M.; Naeemullah, M. Incidence of seed-borne mycoflora in wheat and rice germplasm. Int. J. Agric. Innov. Res. 2014, 2, 720-722.

12. Wiese, M.V. Compendium of Wheat Diseases; American Phytopathological Society: St. Paul, MN, USA, 1987.

13. Moura, A.B.; Santos, A.G.; Farias, C.R.J.d.; Ludwig, J.; Corrêa, B.O.; Soares, V.N. Combination of biocontrol bacteria for rice seeds microbiolization: Incidence and transmission of Bipolaris oryzae, and plant growth. J.Seed Sci. 2018, 40, 378-387. [CrossRef]

14. Benítez, T.; Rincón, A.M.; Limón, M.C.; Codon, A.C. Biocontrol mechanisms of Trichoderma strains. Int. Microbiol. 2004, 7, $249-260$.

15. Ji, P.; Li, W.; Zheng, Y.; Wang, Z.; Huo, Q.; Hua, C.; Han, C. Isolation and identification of four novel biocontrol Bacillus strains against wheat sharp eyespot and their growth-promoting effect on wheat seedling. Int. J. Agric. Biol. 2019, 21, 282-288.

16. Zrcková, M.; Capouchová, I.; Paznocht, L.; Eliášová, M.; Dvořák, P.; Konvalina, P.; Janovská, D.; Orsák, M.; Bečková, L. Variation of the total content of polyphenols and phenolic acids in einkorn, emmer, spelt and common wheat grain as a function of genotype, wheat species and crop year. Plant Soil Environ. 2019, 65, 260-266. [CrossRef]

17. Vinale, F.; Sivasithamparam, K.; Ghisalberti, E.L.; Marra, R.; Woo, S.L.; Lorito, M. Trichoderma-plant-pathogen interactions. Soil Biol. Biochem. 2008, 40, 1-10. [CrossRef]

18. Singh, B.; Singh, A.; Singh, B.; Singh, H. Trichoderma harzianum elicits induced resistance in sunflower challenged by Rhizoctonia solani. J. Appl. Microbiol. 2014, 116, 654-666. [CrossRef] 
19. Keswani, C.; Mishra, S.; Sarma, B.K.; Singh, S.P.; Singh, H.B. Unraveling the efficient applications of secondary metabolites of various Trichoderma spp. Appl. Microbiol. Biotechnol. 2014, 98, 533-544. [CrossRef]

20. Woo, S.L.; Ruocco, M.; Vinale, F.; Nigro, M.; Marra, R.; Lombardi, N.; Pascale, A.; Lanzuise, S.; Manganiello, G.; Lorito, M. Trichoderma-based products and their widespread use in agriculture. Open Mycol. J. 2014, 8, 71-126. [CrossRef]

21. Jain, A.; Singh, A.; Chaudhary, A.; Singh, S.; Singh, H.B. Modulation of nutritional and antioxidant potential of seeds and pericarp of pea pods treated with microbial consortium. Food Res. Int. 2014, 64, 275-282. [CrossRef]

22. Sood, M.; Kapoor, D.; Kumar, V.; Sheteiwy, M.S.; Ramakrishnan, M.; Landi, M.; Araniti, F.; Sharma, A. Trichoderma: The "secrets" of a multitalented biocontrol agent. Plants 2020, 9, 762. [CrossRef]

23. Degani, O.; Rabinovitz, O.; Becher, P.; Gordani, A.; Chen, A. Trichoderma longibrachiatum and Trichoderma asperellum confer growth promotion and protection against late wilt disease in the field. J. Fungi 2021, 7, 444. [CrossRef]

24. Compant, S.; Duffy, B.; Nowak, J.; Clément, C.; Barka, E.A. Use of plant growth-promoting bacteria for biocontrol of plant diseases: Principles, mechanisms of action, and future prospects. Appl. Environ. Microbiol. 2005, 71, 4951-4959. [CrossRef]

25. Glick, B.R. Plant growth-promoting bacteria: Mechanisms and applications. Scientifica 2012, 2012, 963401. [CrossRef]

26. Hampton, J.G.; Boelt, B.; Rolston, M.; Chastain, T. Effects of elevated $\mathrm{CO}_{2}$ and temperature on seed quality. J. Agric. Sci. 2013, 151, 154-162. [CrossRef]

27. Hampton, J. Producing quality seed: The problem of seed vigour. Curr. Res. Seeds N. Z. 2000, 7, $53-67$.

28. Dornbos, D.L. Production environment and seed quality. In Seed Quality; CRC Press: Boca Raton, FL, USA, $2020 ;$ pp. 119-152.

29. Febri, D.; Anizan, I.; Che, R.; Ahmad, H.S.; Muhammad, H.R.; Wan, M. Enhancement of rice seed germination and vigour by Trichoderma spp. Res. J. Appl. Sci. Eng. Tech. 2014, 7, 4547-4552.

30. Okoth, S.A.; Otadoh, J.A.; Ochanda, J.O. Improved seedling emergence and growth of maize and beans by Trichoderma harziunum. Trop. Subtrop. Agroecosyst. 2011, 13, 65-71.

31. Luz, W.C. Effect of bioprotectors on seed pathogens, seed emergence, and corn yield. Fitopatol. Bras. 2001, 26, 16-20. [CrossRef]

32. Shoresh, M.; Harman, G.E.; Mastouri, F. Induced systemic resistance and plant responses to fungal biocontrol agents. Annu. Rev. Phytopathol. 2010, 48, 21-43. [CrossRef] [PubMed]

33. Machado, R.G.; de Sá, E.L.S.; Damasceno, R.G.; Hahn, L.; Almeida, D.; Moraes, T.; de Oliveira Camargo, F.A.; Reartes, D.S. Promoção de crescimento de Lotus corniculatus L. e Avena strigosa schreb pela inoculação conjunta de Trichoderma harzianum e rizóbio. Ciênc. Nat. 2011, 33, 111-126.

34. Contreras-Cornejo, H.A.; Macías-Rodríguez, L.; Del-Val, E.; Larsen, J. Ecological functions of Trichoderma spp. and their secondary metabolites in the rhizosphere: Interactions with plants. FEMS Microbiol. Ecol. 2016, 92, fiw036. [CrossRef]

35. Imran, M.; Neumann, G.; Romheld, V. Nutrient Seed Priming Improves Germination Rate and Seedling Growth under Submergence Stress at Low Temperature. In Competition for Resources in a Changing World: New Drive for Rural Development; University of Hohenheim: Stuttgart, Germany, 2008.

36. Iqbal, S.; Farooq, M.; Nawaz, A.; Rehman, A. Optimizing boron seed priming treatments for improving the germination and early seedling growth of wheat. J. Agric. Soc. Sci. 2012, 8, 57-61.

37. Mondal, S.; Bose, B. Impact of micronutrient seed priming on germination, growth, development, nutritional status and yield aspects of plants. J. Plant Nutr. 2019, 42, 2577-2599. [CrossRef]

38. Aboutalebian, M.; Ekbatani, G.Z.; Sepehri, A. Effects of on-farm seed priming with zinc sulfate and urea solutions on emergence properties, yield and yield components of three rainfed wheat cultivars. Ann. Biol. Res. 2012, 3, 4790-4796.

39. Foti, R.; Abureni, K.; Tigere, A.; Gotosa, J.; Gere, J. The efficacy of different seed priming osmotica on the establishment of maize (Zea mays L.) caryopses. J. Arid Environ. 2008, 72, 1127-1130. [CrossRef]

40. Soleimanzadeh, H. Effect of seed priming on germination and yield of corn. Int. J. Agric. Crop Sci. IJACS 2013, 5, 366-369.

41. Harris, D.; Rashid, A.; Miraj, G.; Arif, M.; Shah, H. 'On-farm'seed priming with zinc sulphate solution-A cost-effective way to increase the maize yields of resource-poor farmers. Field Crops Res. 2007, 102, 119-127. [CrossRef]

42. Atique-ur-Rehman; Farooq, M.; Cheema, Z.A.; Wahid, A. Role of boron in leaf elongation and tillering dynamics in fine-grain aromatic rice. J. Plant Nutr. 2013, 36, 42-54. [CrossRef]

43. Afrayeem, S.M.; Chaurasia, A. Effect of zinc oxide nanoparticles on seed germination and seed vigour in chilli (Capsicum annuum L.). J. Pharmacogn. Phytochem. 2017, 6, 1564-1566.

44. Poštić, D.; Štrbanović, R.; Stanojković-Sebić, A.; Tabaković, M.; Milivojević, M.; Jovanović, S.; Stanisavljević, R. Increasing the pepper seed quality using mycorrhizal fungi. J. Process. Energy Agric. 2019, 23, 66-68. [CrossRef]

45. Štrbanović, R.; Poštić, D.; Tabaković, M.; Knežević, J.; Živanović, L.; Stanisavljević, R. Effects of pre-sowing seed treatments for improving germination and the growth of pepper and tomato seedlings. Acta Sci. Pol. Hortorum Cultus 2021, 20, 101-109. [CrossRef]

46. Tavares, L.C.; Fonseca, D.Â.R.; Brunes, A.P.; Rufino, C.d.A.; Meneguello, G.E.; Barros, A.C.S.A. Performance of rice seeds treated with zinc, boron, and molybdenum. J. Seed Sci. 2013, 35, 532-539. [CrossRef]

47. Freiberg, J.A.; Ludwig, M.P.; Avelar, S.A.G.; Girotto, E. Seed treatment and its impact on wheat crop yield potential. J. Seed Sci. 2017, 39, 280-287. [CrossRef]

48. de Oliveira, J.B.; Muniz, P.; Peixoto, G.H.S.; de Oliveira, T.A.; Duarte, E.A.; Rodrigues, F.; Carvalho, D.D.C. Promotion of seedling growth and production of wheat by using Trichoderma spp. J. Agric. Sci. 2018, 10, 267-276. [CrossRef] 
49. Martínez-Medina, A.; Roldán, A.; Albacete, A.; Pascual, J.A. The interaction with arbuscular mycorrhizal fungi or Trichoderma harzianum alters the shoot hormonal profile in melon plants. Phytochemistry 2011, 72, 223-229. [CrossRef]

50. Sofo, A.; Scopa, A.; Manfra, M.; De Nisco, M.; Tenore, G.; Troisi, J.; Di Fiori, R.; Novellino, E. Trichoderma harzianum strain T-22 induces changes in phytohormone levels in cherry rootstocks (Prunus cerasus $\times$ P. canescens). Plant Growth Regul. 2011, 65, 421-425. [CrossRef]

51. Harman, G.E. Myths and dogmas of biocontrol changes in perceptions derived from research on Trichoderma harzinum T-22. Plant Dis. 2000, 84, 377-393. [CrossRef]

52. Hoyos-Carvajal, L.; Orduz, S.; Bissett, J. Growth stimulation in bean (Phaseolus vulgaris L.) by Trichoderma. Biol. Control 2009, 51, 409-416. [CrossRef]

53. Feledyn-Szewczyk, B.; Cacak-Pietrzak, G.; Lenc, L.; Stalenga, J. Rating of spring wheat varieties (Triticum aestivum L.) according to their suitability for organic agriculture. Agronomy 2020, 10, 1900. [CrossRef]

54. Banjac, N.; Stanisavljević, R.; Dimkić, I.; Velijević, N.; Soković, M.; Ćirić, A. Trichoderma harzianum IS005-12 promotes germination, seedling growth and seedborne fungi suppression in Italian ryegrass forage. Plant Soil Environ. 2021, 67, 130-136. [CrossRef]

55. Gravel, V.; Antoun, H.; Tweddell, R.J. Growth stimulation and fruit yield improvement of greenhouse tomato plants by inoculation with Pseudomonas putida or Trichoderma atroviride: Possible role of indole acetic acid (IAA). Soil Biol. Biochem. 2007, 39, 1968-1977. [CrossRef]

56. Silva, F.F.d.; Castro, E.d.M.; Moreira, S.I.; Ferreira, T.C.; Lima, A.E.d.; Alves, E. Emergência e análise ultraestrutural de plântulas de soja inoculadas com Sclerotinia sclerotiorum sob efeito da aplicação de Trichoderma harzianum. Summa Phytopathol. 2017, 43, 41-45. [CrossRef]

57. Shukla, N.; Awasthi, R.; Rawat, L.; Kumar, J. Seed biopriming with drought tolerant isolates of Trichoderma harzianum promote growth and drought tolerance in Triticum aestivum. Ann. Appl. Biol. 2015, 166, 171-182. [CrossRef]

58. Wang, J.; Hasanalieva, G.; Wood, L.; Anagnostopoulos, C.; Ampadogiannis, G.; Bempelou, E.; Kiousi, M.; Markellou, E.; Iversen, P.O.; Seal, C.; et al. Effect of wheat species (Triticum aestivum vs. T. spelta), farming system (organic vs. conventional) and flour type (whole grain vs. white) on composition of wheat flour-results of a retail survey in the UK and Germany-3. Pesticide residue content. Food Chem. X 2020, 7, 100089. [CrossRef] [PubMed]

59. Wang, J.; Baranski, M.; Korkut, R.; Kalee, H.A.; Wood, L.; Bilsborrow, P.; Janovska, D.; Leifert, A.; Winter, S.; Willson, A.; et al. Performance of modern and traditional spelt wheat (Triticum spelta) varieties in rain-fed and irrigated, organic and conventional production systems in a semi-arid environment; results from exploratory field experiments in Crete, Greece. Agronomy 2021, 11, 890. [CrossRef]

60. Guardado-Valdivia, L.; Tovar-Pérez, E.; Chacón-López, A.; López-García, U.; Gutiérrez-Martínez, P.; Stoll, A.; Aguilera, S. Identification and characterization of a new Bacillus atrophaeus strain B5 as biocontrol agent of postharvest anthracnose disease in soursop (Annona muricata) and avocado (Persea americana). Microbiol. Res. 2018, 210, 26-32. [CrossRef]

61. Abdel-Monaim, M.F.; Abdel-Gaid, M.A.; Zayan, S.A.; Nassef, D.M. Enhancement of growth parameters and yield components in eggplant using antagonism of Trichoderma spp. against Fusarium wilt disease. Int. J. Phytopathol. 2014, 3, 33-40. [CrossRef]

62. Mukhtar, I.; Hannan, A.; Atiq, M.; Nawaz, A. Impact of Trichoderma species on seed germination in soybean. Pak. J. Phytopathol. 2012, 24, 159-162.

63. Nikolić, I.; Berić, T.; Dimkić, I.; Popović, T.; Lozo, J.; Fira, D.; Stanković, S. Biological control of Pseudomonas syringae pv. aptata on sugar beet with Bacillus pumilus SS-10.7 and Bacillus amyloliquefaciens (SS-12.6 and SS-38.4) strains. J. Appl. Microbiol. 2019, 126, 165-176. [CrossRef] [PubMed]

64. International Seed Testing Association (ISTA). Rules for Testing Seeds; ISTA: Zurich, Switzerland, 2020.

65. Stanisavljevic, R.; Đjokic, D.; Milenkovic, J.; Đukanovic, L.; Stevovic, V.; Simic, A.; Dodig, D. Seed germination and seedling vigour of Italian ryegrass, cocksfoot and timothy following harvest and storage. Cienc. Agrotecnol. 2011, 35, 1141-1148. [CrossRef]

66. Gianinetti, A. Basic features of the analysis of germination data with generalized linear mixed models. Data 2020, 5, 6. [CrossRef]

67. R Core Team. R-Statistics, a Language and Environment for Statistical Computing (Version 3.4.4); R Foundation for Statistical Computing: Vienna, Austria, 2018.

68. Minitab Inc. Version 16.1.0. State College, Pennsylvania, USA, Was Used to Process Data (Free Version). Available online: https: / / www.minitab.com/en-us/ (accessed on 17 November 2020). 